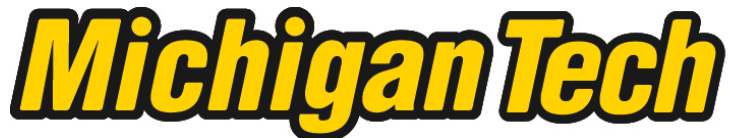 \\ Michigan Technological University Create the Future Digital Commons @ Michigan Tech
}

\section{Balancing wildlife and bioenergy values on private forestlands in the eastern Upper Peninsula of Michigan}

Karl Makinen

Michigan Technological University

Follow this and additional works at: https://digitalcommons.mtu.edu/etds

Part of the Environmental Policy Commons

Copyright 2010 Karl Makinen

\section{Recommended Citation}

Makinen, Karl, "Balancing wildlife and bioenergy values on private forestlands in the eastern Upper Peninsula of Michigan", Master's Thesis, Michigan Technological University, 2010.

https://doi.org/10.37099/mtu.dc.etds/290

Follow this and additional works at: https://digitalcommons.mtu.edu/etds

Part of the Environmental Policy Commons 


\title{
Balancing Wildlife and Bioenergy Values on Private Forestlands in the Eastern Upper Peninsula of Michigan
}

\author{
By \\ Karl Makinen \\ A THESIS \\ Submitted in partial fulfillment of the requirements for the degree of \\ MASTER OF SCIENCE IN ENVIRONMENTAL POLICY
}

Michigan Technological University

2010

Copyright $\odot$ Karl Makinen 2010 
This thesis, "Balancing Wildlife and Bioenergy Values on Private Forestlands in the Eastern Upper Peninsula of Michigan," is hereby approved in partial fulfillment of the requirements of the Degree of MASTER OF SCIENCE IN ENVIRONMENTAL POLICY.

Department of Social Sciences

Environmental Policy Graduate Program

Signatures:

Thesis Advisor:

Dr. Kathleen E. Halvorsen

Department Chair:

Dr. Patrick E. Martin

Date: 


\section{Acknowledgements}

First and foremost I would like to thank Dr. Kathleen Halvorsen for all of your advice, guidance, assistance and moral support throughout my time at MTU. I also want to thank my committee members Dr. Linda Nagel and Dr. Audrey Mayer.

I would like to acknowledge the contributions made by all the professors I was fortunate enough to spend time with, Dr. Joe Bump, Dr. David Flaspohler, Dr. Hugh Gorman, Dr. Jeff Henquinet, Dr. Ann MacLean, Dr. Carol MacLennan, Dr. Alex Mayer, Dr. Thomas Pypker, and Dr. Barry Solomon, thank you for your dedication to teaching.

I would like to thank all of my colleagues who supported, and encouraged me along the way. In particular, I would like to thank Andrew Kozich, Kaye LaFond, Laura Pavlot, Susan Balint, Nick Johnson, Michelle Freeman and Brian Pattullo. I have many great memories of the time I spent with all of you.

I would like to thank Mrs. Karen Aho and Mrs. Gina Stevens for their expertise in all things administrative. Not only did you solve every problem I had...you did so with a smile. Thank you.

I would like to thank all of the private landowners who were very kind and thoughtful in volunteering their valuable time to assist me in this research.

Last but certainly not least I would like to thank my family. Lisa thank you for all of your love and support, you keep me sane. Mom and Dad, nothing could have been possible without your unwavering support throughout my entire life, words can not express my gratitude. 


\section{Table of Contents}

Abstract................................................................... 5

Chapter 1: Introduction............................................. 6

Chapter 2: Background Information..................................... 9

Mascoma Corporation's plans for a commercial facility ................ 9

History of ethanol................................................ 10

Shortcomings of reliance on petroleum............................... 14

Is cellulosic ethanol a viable alternative? .............................. 16

Landowner incentive programs.......................................................... 19

Chapter 3: Scholarly Literature Review..................................... 24

Non-industrial private forestlands...................................24

Managing for biofuels and biodiversity............................... 26

Wildlife management on private lands............................. 28

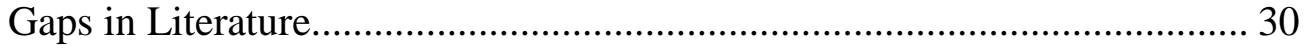

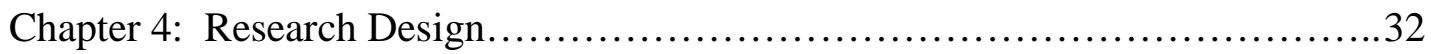

Hypotheses.................................................. 39

Chapter 5: Results..................................................... 40

Landowners and timber harvesting .............................. 40

Wildlife management interests of private landowners....................44

Landowner values and beliefs about climate change

and energy independence........................................... 48

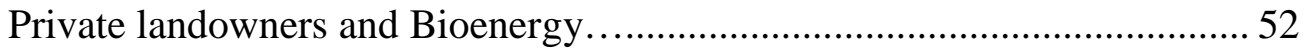

Hypotheses..................................................57

Chapter 6: Discussion.................................................. 59

Chapter 7: Conclusion................................................62

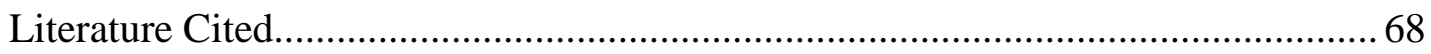

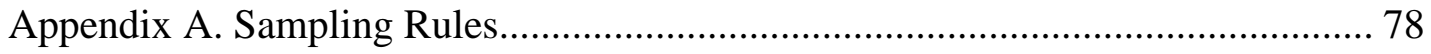

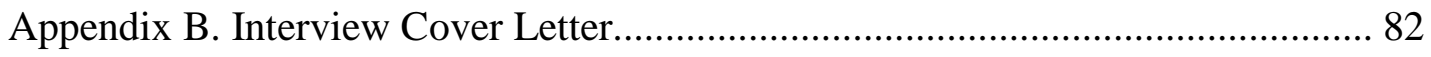

Appendix C. Landowner Response Letter..................................................... 84

Appendix D. Interview Questions Protocol........................................................85 


\begin{abstract}
There is interest in developing a reliable, sustainable, domestic U.S. biofuels industry. A domestic biofuels industry has the potential to provide economic, environmental, and national security benefits on a local, regional, national, and global level. The Mascoma Corporation plans to develop a cellulosic ethanol facility in Michigan's eastern Upper Peninsula. The primary feedstock of the plant site would be trees sourced within a 150 mile supply radius. In the eastern Upper Peninsula, this radius encompasses Alger, Chippewa, Delta, Luce, Mackinac, and Schoolcraft counties. In these six counties there are 1,320,500 acres of NIPF (non-industrial private forestlands). These acres account for $40 \%$ of the total timberland in these six counties. Thus it is likely that in order for the successful implementation of a cellulosic ethanol facility the support of local NIPF owners will be necessary.

This thesis presents research on how eastern Upper Peninsula forest landowners think about and manage their land. It is based on 48 in-depth interviews with these landowners. The goal was to determine how landowner values and beliefs, on a variety of issues including wildlife management, land management, biofuels development, and climate change, are expressed through both their current management decisions, and possibly their future land management decisions. Some of the values articulated by the landowners in this study included biodiversity protection, conservation of healthy game populations, and the production of high-value timber. Understanding the values and beliefs of landowners in the eastern Upper Peninsula of Michigan is critical for successfully developing a sustainable regional woody bioenergy.
\end{abstract}




\section{Chapter 1: Introduction}

Over the past couple of decades it has become increasingly apparent that our nation's energy policy must move in a new direction. It is essential for environmental, economic, and national/energy security reasons that we replace gasoline with a domestically produced sustainable transportation fuel (Lynd and Wang 2004; Dale 2007; Farrell et al. 2006; Greene 2004). A fuel that is an attractive alternative to gasoline is cellulosic ethanol, which can be produced from a variety of biomass based feedstocks including wood, grasses, agricultural residues, and municipal wastes (Lave et al. 2001; Wyman 2007; Greene and Mugica 2005). According to the Biomass Program run by the U.S. Department of Energy, one reason that cellulosic ethanol is attractive as an alternative fuel, is that cellulosic ethanol has a much higher energy return on investment as compared to other transportation fuels such as gasoline or corn derived ethanol. That is, to get the fuel to the pump, it takes far fewer BTUs of fossil energy to produce a gallon of cellulosic ethanol as compared to gasoline. However, many barriers such as investment in commercial cellulosic ethanol facilities and availability of sustainably produced biofuel feedstock must be addressed before our country will be able to transition to a biomass based ethanol on an industrial scale (Wyman 2007).

There are many people in government, industry, and academia conducting research aimed at displacing significant amounts of gasoline with cellulosic ethanol (Lynd and Wang 2004; Dale 2007; Farrell et al. 2006; Greene 2004; Lave et al. 2001; Wyman 2007; Greene and Mugica 2005; Perlack et al. 2005). There is an estimated annual availability of 1.3 billion dry tons of sustainably produced biomass that could be available for bioenergy production (Perlack et al. 2005). Depending on the material 
being used, estimates of conversion rates range from 60-100 gallons of cellulosic ethanol per dry ton of biomass (DiPardo 2004). Using these conversion rates, it calculates out to a potential annual production range of 78-130 billion gallons of cellulosic ethanol, or 5287 billion gallons of gasoline equivalent. The U.S. consumes about 140 billion gallons of gasoline annually (U.S. Energy Information Administration 2010). According to these estimates the potential exists to replace up to $60 \%$ of the gasoline consumed in the United States with cellulosic ethanol. Despite this potential, the current U.S. renewable fuel standard requires 16 billion gallons of cellulosic ethanol by 2022 . If met that goal would represent approximately $15 \%$ of domestic gasoline consumption.

In addition to the benefits that could be derived from cellulosic ethanol commercialization, there are also concerns that must be addressed in order to ensure that cellulosic ethanol is both renewable and sustainable. There is a potential for land use changes if 1.3 billion dry tons of biomass are harvested annually (Perlack 2005; Kim et al. 2009). The expanded use of biofuels and the possible associated land use changes for the production of bioenergy feedstocks, could impact the efforts to conserve wildlife and protect biodiversity (Flaspohler et al. 2009; Groom et al. 2008).

My research will attempt to improve upon our collective knowledge regarding the potential availability of woody biomass feedstock from non-industrial private forestlands (NIPF). I will primarily seek to answer the question: How interested are eastern Upper Peninsula landowners in participating in woody biomass markets? My hope is that in addressing this question, I will improve our understanding of not only the availability of biomass that can be sustainably harvested from these lands for cellulosic ethanol production, but also the reasons or factors that landowners may decide to use their lands 
for the production of feedstocks for biofuels. Furthermore, I hope to determine how landowners conceive of sustainability through the examination of various factors, such as an owner's: desire to protect biodiversity, provide quality habitat for game species, concern about energy independence and, beliefs about climate change. Lastly, by determining what motivates landowners, I hope to contribute to the identification of policy options which can help encourage owners of NIPF to use their lands, in a sustainable manner, to provide cellulosic ethanol feedstock while protecting biodiversity. 


\section{Chapter 2: Background Information}

\section{Mascoma plans a cellulosic ethanol facility for the eastern Upper Peninsula of}

Michigan

On July $19^{\text {th }}, 2007$, Michigan's Governor Jennifer Granholm, and Mascoma Corporation CEO Bruce Jamerson, announced the Massachusetts-based company's plans to build a commercial cellulosic ethanol facility in the town of Kinross, located in Michigan's eastern Upper Peninsula. The plant would be the first facility of its kind to produce ethanol from wood-based materials on a commercial scale (State of Michigan 2008). Governor Granholm stated, "Cellulosic is the next step in the wide-scale ethanol production, and this puts Michigan on the leading edge of technology." Discussing why Michigan was chosen as the site for this plant, CEO Bruce Jamerson said, "Michigan is an excellent state for one of the country's first cellulosic ethanol plants, given its many tons of biomass available for conversion into low-carbon, domestically produced fuel."

On June $27^{\text {th }}, 2008$ Michigan's Governor Jennifer Granholm and the CEO of Mascoma Corporation announced plans for a cooperative strategic relationship in order to ensure the success of Mascoma's plan to build a commercial cellulosic ethanol plant in Michigan's Upper Peninsula (State of Michigan 2008). Members of the agreement include the Michigan Economic Development Corporation, JM Longyear, Michigan State University, and Michigan Technological University. These groups and university professionals are working together to ensure long-term sustainability of both the cellulosic ethanol plant and the surrounding forest land. 
Mascoma's Frontier Renewable Resources project is projected to be completed in 2012; whether that goal will be met remains to be seen. Ultimately, the plant is expected to produce approximately 40 million gallons of cellulosic ethanol a year. If completed, the plant will provide numerous benefits to society. The plant will provide an estimated 60 local jobs, and hundreds of other related jobs in such sectors as the forest products industry, transportation, and construction. These jobs and the company will provide revenue for local, state, and federal governments. It will help to reduce our dependence on foreign oil, greenhouse gas emissions, and will increase our energy security.

\section{A History of Ethanol Production}

Ethanol has been used as a transportation fuel going back all the way to the late 1800's. Ford's Model T was the original flex-fuel vehicle, capable of running on both ethanol and gasoline (Solomon et al. 2007). However, shortly thereafter, petroleum became our country's preferred transportation fuel due to its lower production costs as compared to ethanol. As gasoline began to dominate the market share of the transportation fuel industry, the demand for ethanol all but evaporated. Despite the fact that petroleum-based fuels dominate the transportation fuel market, ethanol has been and will continue to be a component of our nation's transportation fuel supply.

Throughout our history interest in ethanol has ebbed and flowed on more than one occasion. Generally, production of ethanol responds to various government policies that may mandate production levels or in response to supply and demand of substitutes such as gasoline (Solomon et al. 2007). Public interest in ethanol as an alternative fuel source to gasoline generally follows increases in the price of oil (Serra et al. 2008). One of the 
most important events that stimulated US concern about the dangers of relying on foreign energy supplies was the 1973 OPEC Arab oil embargo (Solomon et al. 2007). Shortly thereafter, the federal government began to create policies promoting the generation and use of domestic supplies of energy such as ethanol. An example of such a policy is the Energy Tax Act of 1978, which emphasized fuel efficiency and renewable energy. Additional examples of events that affect the price of crude oil include: natural disasters that cause supply disruptions such as hurricanes in the Gulf of Mexico, increasing world demand as countries such as China and India utilize more petroleum as they industrialize, and geopolitical instability in oil producing areas such as Niger and Iraq (U.S. Energy Information Administration). Although the movement to increase the use of renewable fuels has been painfully slow, the U.S. government has enacted policies over the past few decades designed to move toward a reliable and sustainable domestic supply of transportation fuel.

Starting in the late 1970's and continuing to the turn of the millennium, numerous polices contributed to the increase in total domestic ethanol production (Solomon et. al. 2007). The Federal Energy Tax Act of 1978 provided a $\$ 0.40 /$ gallon of ethanol production subsidy, which helped launch the industry (Tyner 2008). This ethanol subsidy continues and is currently $\$ 0.51 /$ gallon (Tyner 2008). In 1980, the US Congress created supports for ethanol producers including loans and price guarantees (Solomon et al. 2007). While these policies contributed to the growth of the ethanol industry, when gasoline prices bottomed out in the 1980's people seemed to forget the lessons learned from the 1973 OPEC Arab oil embargo. Consequently, very little ethanol industry growth occurred. Despite relatively low prices the federal government continued to make 
small incremental steps promoting ethanol as a gasoline alternative. For instance, the 1992 Energy Policy Act provided tax deductions for vehicles that could run on E85, a blend of $85 \%$ ethanol and $15 \%$ gasoline. Furthermore, this act mandated that newly purchased government vehicles must be flex-fuel vehicles capable of running on E85 (Solomon et al. 2007). Despite enacting these policies, there was little increase in ethanol production between 1978 and 2000 (Figure 1).

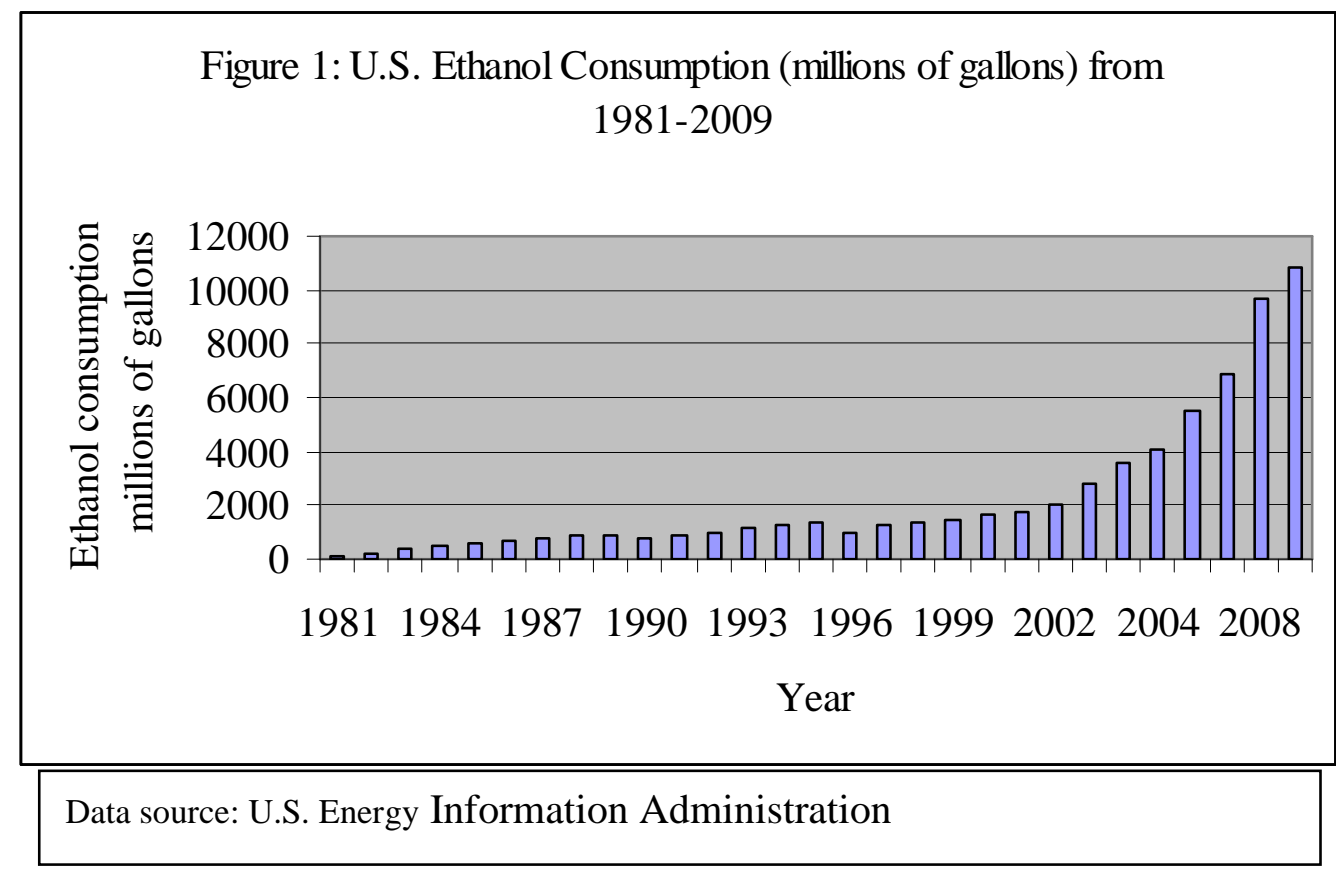

However in 2000, the United States began to realize a marked increase in ethanol production. One of the main causes for this increase was the new methyl tertiary butyl ether (MTBE) restrictions. By 2005, twenty states had banned this fuel additive due to environmental concerns (Tyner 2008). These bans have increased the use of ethanol due to its ability to successfully replace MTBE (Solomon et al. 2007). Thus in 2004, 3.4 billion gallons of ethanol were blended into U.S. gasoline. This accounted for about $2 \%$ of the gasoline volume sold domestically (Farrell et al. 2006). Then the 2005 Energy 
Policy Act mandated that 7.5 billion gallons of "renewable fuel" (ethanol) be blended with U.S. gasoline by 2012 (Tyner 2008).

In 2007, the U.S. Congress passed the Energy Independence and Security Act of 2007 (EISA). EISA went even further, mandating a renewable fuel standard (RFS2) of 36 billion gallons of consumption per year by 2022 (Tyner 2008). Of those 36 billion gallons, cellulosic ethanol is mandated to contribute 16 billion gallons to the total. While EISA mandates the production of renewable fuel, it excludes cellulosic ethanol made from many types of woody biomass from counting toward the RFS2 mandates. Most woody biomass on public lands is exempted from counting as renewable, with the exception being those materials harvested near buildings which are located in areas of high fire risk. While not known, this definition of renewable biomass may have come about in response to lobbying groups which promote a no-cut policy on federal lands. There was probably a concern that overharvesting of woody biomass would occur on federal lands. With virtually all federal lands exempted from counting as renewable biomass, the likelihood of meeting the renewable fuel standard (RFS2) mandated in EISA is diminished. The exclusion of these federal lands means there will be far fewer acres of biomass available for any commercial cellulosic ethanol facility. However, the RFS2, while important, would not come near to eliminating our dependence on domestic or foreign oil. According to the U.S. Energy Information Administration, the U.S. consumes approximately 140 billion gallons of gasoline a year. Sixteen billion gallons of cellulosic ethanol would represent only a small percentage of the total transportation fuel consumed annually. Consequently, the U.S. will have to enact additional energy policies which encourage the growth of cellulosic ethanol, biodiesel, and other biofuels, as well as 
increase fuel efficiency and energy conservation, if the U.S. government hopes to successfully replace gasoline with cleaner renewable fuels.

\section{Shortcomings of Reliance on Petroleum}

The reasons for replacing petroleum are numerous and potentially critical. The primary environmental reason is that the burning of gasoline accounts for approximately one-third of U.S. greenhouse gas emissions (Wyman 2007). Carbon dioxide, which is one of the main byproducts of fossil fuel combustion, is a known greenhouse gas, which leads to climate change. As the concentration of greenhouse gases continues to increase, we will see a corresponding increase in mean global temperature (IPCC 4th Assessment Report 2007). The increase in global temperature will have many effects that could be catastrophic for many regions of the world. We can expect a rise in sea level as the ice sheets on Greenland and Antarctica melt (IPCC 4th Assessment Report 2007). These rises in sea level would be devastating for the large number of people who live near the world's oceans. Many of the world's coastal areas are expected to experience more intense and frequent hurricane activity due to the increase in thermal energy contained in the oceans (IPCC 2007 4th Assessment Report). Some of the other expected problems include increase mid-latitude desertification, shifts in weather patterns, arctic sea ice loss, and melting of arctic permafrost (IPCC 4th Assessment Report 2007). The few problems mentioned here may only be the tip of the iceberg when it comes to the problems that the world will face if we are unable to drastically reduce our emissions of carbon dioxide.

Another externality associated with our use of oil is that dependence on foreign sources of oil reduces the national security of the United States (Dale 2007; Greene and 
Mugica 2005; Lave et. al. 2001; Tyner and Taheripour 2007). On September 11, 2001 our country suffered the worst attack on domestic soil since Pearl Harbor. This attack launched our country into what has come to be known as the War on Terror. Shortly thereafter, the men and women in our armed forces were sent to lay their lives on the line to defend our country from another horrific attack. Jim Woolsey, a former director of the Central Intelligence Agency, has stated that the twin pillars upon which our enemy in the War on Terror stand are the illegal drug trade and the oil trade (Dale 2007). Woolsey goes on to state that this is the only war that America has fought in which we are funding both sides. We fund our armed forces with our tax dollars, and we fund the enemy with the money we spend to import oil (Dale 2007). Thus it is clear, in order to improve our national security and help our military succeed it is essential that we find a transportation fuel alternative to gasoline so our country can reduce our dependence on foreign oil.

Dependence on gasoline is also a threat to the U.S. economy (Copulos 2007). A major cost to the U.S. economy comes in the form of defense expenditures. The U.S. currently spends about 130-140 billion dollars annually to defend access to Persian Gulf oil (Copulos 2007). Another threat to the U.S. economy stems from the transfer of wealth from oil consumers to oil producers, which occurs as oil prices rise (Greene and Ahmad 2005). Furthermore, when the U.S. experiences price shocks, there is an associated reduction in the U.S. GDP (Jones et al. 2004). Petroleum is a non-renewable resource in increasing worldwide demand. As supply decreases and demand increases, U.S. producers and consumers will pay more for energy. As the cost of energy increases, the cost of most products increases due to higher transportation costs. For these 
environmental, national security, and economic reasons it is essential to find a domestically produced, sustainable alternative to gasoline.

\section{Is Cellulosic Ethanol A Viable Alternative?}

In order to be considered a viable alternative to gasoline a biofuel should be economically competitive, provide a net energy gain, reduce negative environmental impacts, and be produced on an industrial scale without reducing food availability (Hill et al. 2006). Numerous studies claim that cellulosic ethanol meets these criteria (Greene and Mugica 2005; Lynd and Wang 2004; Wyman 1999; Wyman 2007). It is projected that by 2015 , cellulosic ethanol will cost between $\$ 0.59$ and $\$ 0.91 /$ gallon of gasoline equivalent to produce (Greene 2004). The average cost of gasoline production was \$0.91/gallon between 2000 and 2004 (Greene 2004; Solomon et al. 2007). This takes into consideration the fact that on a gallon per gallon basis ethanol contains about $2 / 3$ the energy of gasoline and the cost of production reflects this fact. Considering that the average price of gasoline in the U.S. in January of 2004 was \$1.49, and January of 2010 it was $\$ 2.62$ (U.S. Energy Information Administration), cellulosic ethanol is now even more economically competitive than at the time Greene 2004 was published.

There has been considerable disagreement in the scientific community concerning the net energy ratios of various biofuels. One side of the debate claims that it takes approximately $50 \%$ more energy to produce a liter of cellulosic ethanol than is harnessed upon combustion (Pimentel and Patzek 2005). Other studies support similar claims of negative net energy for biofuels (Giampietro et. al. 1997; Lal 2007; Patzek and Pimentel 2005). However, many other studies dispute these negative net energy results (Lynd et 
al. 1991; Lynd et al. 2007; McLaughlin et al. 2006; Solomon et al. 2007). While reading the journals where negative net energy ratios were reported, (Giampietro et. al. 1997; Lal and Pimentel 2007; Patzek and Pimentel 2005) errors in calculations become apparent when compared to other papers. They failed to take into account the energy inputs of cellulosic ethanol byproducts. One of these is lignin, and it constitutes approximately one quarter of the dry mass of wood and can be burned to provide the energy needed to run the ethanol production process (Lave et. al. 2001). By failing to account for this energy input, the net energy ratio becomes skewed to a negative return on energy for cellulosic ethanol. Another issue that Pimentel and Patzek (2005), failed to consider is that gasoline has a negative net energy ratio (Dale 2007; Farrell et. al. 2006; U.S. DOE 2009). The U.S. Department of Energy states that gasoline requires 1.23 Btu of fossil energy inputs to deliver one Btu of gasoline at refueling stations (U.S. DOE 2009). This would make gasoline far less valuable than ethanol, not withstanding the other societal costs associated with gasoline. While there is some disagreement, the majority of studies indicate that cellulosic ethanol does have a positive energy return on investment.

There are many environmental benefits that can be realized with a shift from a transportation system based on petroleum to one based on a renewable fuel such as cellulosic ethanol. An extremely important benefit would be drastic reductions in our nation's greenhouse gas emissions (Farrell et. al. 2006; Greene 2004; Greer 2005). The transportation sector is a major source of domestic greenhouse gas emissions. Replacing gasoline with cellulosic ethanol would reduce greenhouse gas emissions by closing the carbon loop. While it is true that the combustion of ethanol releases $\mathrm{CO}_{2}$, when the next generation of plants grows, an equivalent amount of carbon dioxide is sequestered from 
the atmosphere. The result is the stabilization of the carbon cycle and an overall reduction in greenhouse gas emissions as compared to fossil fuels. Today a significant amount of our solid waste that contains cellulose is discarded in landfills, or burned. Cellulosic ethanol provides an opportunity to use wastes to produce a valuable product while at the same time reducing other environmental impacts. When cellulose-based materials decompose in landfills they produce methane which is a very powerful greenhouse gas. Thus, by reducing the amount of organic waste entering landfills or incineration centers, we could reduce both the amount of methane produced, as well as the air pollution that results from incineration (Wyman 1999).

Studies have shown that cellulosic ethanol can be economically competitive with gasoline, provide a net energy gain, and improve the quality of our environment. However, there are issues with producing cellulosic ethanol on a large scale (Hill et. al. 2006). Determining the amount biomass feedstock for biofuel production is fundamental to the effort of calculating how much U.S. cellulosic ethanol can be sustainably produced. Some feedstock sources are easier to calculate than others. For example, it is well known how much municipal and agricultural waste is produced in the U.S. annually (Lynd 1996). Although separating and procuring these wastes would be difficult, it is an important potential feedstock for cellulosic ethanol production. Forests and agricultural lands provide a much different picture. We do not know what percentage of privately held U.S. lands can or will be used for biofuels production. One of the most cited and discussed studies, was done as a joint venture between the Department of Agriculture and the Department of Energy (Perlack et al. 2005). This study is often referred to as the Billion Ton Study and estimated that enough feedstock could be sustainably produced to 
displace approximately half of U.S. gasoline consumption. However, due to uncertainty about how much land will be dedicated to the production of energy crops, it is difficult to reliably estimate how much feedstock and cellulosic ethanol could be produced.

Many of the problems surrounding the question of how much feedstock will be required to displace gasoline with cellulosic ethanol stem from future uncertainty. We can not be sure how much of an increase in the yields of feedstock per acre we can expect. We do not know how much more fuel efficient cars will be, even 10-15 years from now. We can not be sure how much or even if we will see production efficiency gains. We can not be sure what policies the government may use to promote cellulosic ethanol. All of these uncertainties make it difficult to determine how much feedstock will be necessary to meet the transportation fuel demand in the future. However, it is still important to know how much land will be available for the production of feedstock if we are to make any estimates about the quantity of feedstock that could be potentially available. One of the main goals of my research is to determine how interested eastern Upper Peninsula landowners are in participating in woody biomass markets. Using the amount of land that will be available for the production of feedstock, not the total amount of land existing should provide a much more accurate picture about the production capacity for feedstock that exists in the vicinity of the Mascoma plant.

\section{Landowner Incentive Programs}

If cellulosic ethanol is going to be a viable sustainable alternative to gasoline it must not only fulfill the requirements stated by Hill et al. 2006, it must also protect local landowner values. A potential tool to help assure that bioenergy feedstocks are produced 
and harvested in a sustainable manner and protect landowner values such as the provision of wildlife habitat are landowner incentive programs. These programs are numerous and variable. They are administered by federal and/or state governments. Others landowner incentive programs may be administered by groups such as Ducks Unlimited or other private non-profit organizations.

These landowner incentive programs provide benefits to private landowners, wildlife, and the general public (Potter-Witter 2005). Landowner incentive programs may improve or protect wildlife habitat, prevent development, improve a timber stand, or restore a wetland. They primarily provide landowners with financial and technical assistance, including professional advice, cost-sharing on specific projects, and tax breaks. Some of the main landowner incentive programs are the Forest Stewardship Program, Environmental Quality Incentives Program, American Tree Farm System, Michigan Working Forest Carbon Offset Program, Wildlife Habitat Incentive Program, Landowner Incentive Program, Safe Harbor Program, Conservation Reserve Program, and the Wetlands Reserve Program.

The Forest Stewardship Program (FSP) provides technical assistance, through State forestry agency partners, to nonindustrial private forest owners (NIPF) to encourage and enable active long-term forest management (U.S. Forest Service 2010). A primary focus of the Program is the development of management plans that provide landowners with the information they need to manage their forests for a variety of products and services (U.S. Forest Service 2010).

Michigan's Forest Legacy Program (FLP) is administered by the USDA Forest Service in cooperation with State partners. Its overarching goal is to protect privately 
owned and environmentally significant forest lands from being converted to non-forest uses (U.S. Forest Service 2008). FLP is an entirely voluntary program. It seeks to accomplish its goal by using conservation easements. As stated in the Michigan's Assessment of Needs, conservation easements purchased using FLP funds will restrict development, require sustainable forestry practices, and protect a variety of other values (U.S. Forest Service 2008).

The Environmental Quality Incentives Program (EQIP) is a voluntary program that provides financial and technical assistance to farmers, ranchers, and forest owners who face threats to the natural resources on their land (U.S. Department of Agriculture 2010). Through EQIP, the Natural Resources Conservation Service of the USDA provides financial incentives to producers to promote agricultural production and environmental quality as compatible goals, increase environmental benefits, and help farmers and ranchers meet all environmental regulations (U.S. Department of Agriculture 2010).

The Michigan Tree Farm System, a nonprofit organization, was developed to promote the growing of renewable resources on private lands, while protecting the environment, wildlife habitat, and increasing public understanding of forestry programs such as the Michigan Tree Farm (Stone 2009).

The Michigan Forest Carbon Project uses the Forest Stewardship Program (FSP) and other forest management programs to assist forest owners to access the Chicago Climate Exchange (CCX) in order to trade carbon credits (MI Department of Natural Resources n.d.). The Michigan DNR has developed a technical assistance fund, whose goal is to increase landowner participation by waiving initial inventory fees, in doing so 
the goal is to reduce forest fragmentation and increase the ecosystem services provided by private forests (MI Department of Natural Resources n.d.).

The Wildlife Habitat Incentives Program (WHIP) is a voluntary program for private landowners to develop and improve high quality habitat that supports wildlife populations of National, State, Tribal, and local significance (U.S. Department of Agriculture 2009). Through WHIP, the USDA's Natural Resources Conservation Service (NRCS) provides technical and financial assistance (U.S. Department of Agriculture 2009).

The primary goal of the Landowner Incentive Program is to help private landowners create and manage habitat for species that are rare and/or declining (MI Department of Natural Resources 2010). The Michigan Department of Natural Resources accomplishes this through the program by providing advice, management plans, and financial assistance to individuals and organizations throughout the state that qualify (MI Department of Natural Resources 2010).

In a Safe Harbor agreement, a landowner commits to providing benefits for endangered wildlife, such as enhancing habitats for endangered species or wetland restoration, and the government pledges not to "punish" the landowner as a result (U.S. Fish and Wildlife Service 2010). Its purpose is to provide private landowners with assurances that they will not be penalized by endangered species laws, when they manage their land to conserve listed species (U.S. Fish and Wildlife Service 2010). The US Fish \& Wildlife Service in conjunction with the USDA-Natural Resources Conservation Service administers the program. 
The Conservation Reserve Program (CRP) provides technical and financial assistance to farmers and ranchers to address natural resource concerns on their lands in a way that is both environmentally friendly and cost-effective (U.S. Department of Agriculture 2009). The program is funded through the Commodity Credit Corporation (CCC). CRP is administered by the Farm Service Agency, with the Natural Resources Conservation Service providing land eligibility determinations, planning, and implementation (U.S. Department of Agriculture 2009).

The Wetlands Reserve Program is a voluntary program which helps landowners protect, restore, and improve wetlands (U.S. Department of Agriculture 2010). The USDA Natural Resources Conservation Service provides technical and financial support to landowners for these efforts. The NRCS goal is to improve wetland functions and values, along with wildlife habitat (U.S. Department of Agriculture 2010).

Another goal of my research is to determine how familiar private landowners are with the various landowner incentive programs, and whether they would consider enrolling their land in any of these programs. I am primarily interested in these programs because I believe there is a potential for landowner incentive programs to play a part in ensuring that a cellulosic ethanol industry in the eastern Upper Peninsula of Michigan is sustainable. 


\section{Chapter 3: Scholarly Literature Review}

\section{Non-Industrial Private Forestland}

Approximately 393 million of the 620 million acres of continental U.S. forests are privately owned (Butler and Leatherberry 2004). Of these 393 million acres, 276 million are owned by families (Hodgdon et al. 2007). Private owner classes include corporations, nonprofit organizations, clubs, and individuals. According to the Society of American Foresters, NIPF (non-industrial private forestlands) are defined as forest land that is privately owned by individuals or corporations other than the forest industry (Munsell and Germain 2007). However, in general NIPF often refers to non-corporate forest land. In Michigan, approximately one third (10 million acres) of all forests are classified as NIPF. These private forest lands have the potential to provide a tremendous amount of woody biomass for the production of cellulosic ethanol. However, significant issues must be addressed before the potential of NIPF land can be realized.

Landowner values and beliefs are an important factor in feedstock availability from these lands. Many landowners value their land for reasons that do not include timber harvesting (Erickson et al. 2002). Potential landowner values include recreation, scenery, biodiversity, investment, privacy, and timber production (Butler et. al. 2007; Potter-Witter 2005). It will be critical to understand landowner values in order to be able to make estimates about how likely private landowners are to participate in bioenergy markets as well as how much feedstock will come from NIPFs. For example, some owners may dedicate all of their land to biofuels feedstock production, using silvicultural methods known to increase yield, because they value the economic benefits of timber 
production and there is a market for the product. Other forest owners may only use a portion of their land for feedstock production, because they have multiple objectives for their land. For instance, while the owner may value timber production, they may harvest timber or other biomass to improve habitat for the game species that they hunt (Butler 2008; Baughman et al. 1998). Other owners will never harvest trees or other biomass from their lands because they mainly value the biodiversity and aesthetics of their property. One study found that twenty six percent of family forest owners have harvested timber from their lands in the past (Butler and Leatherberry 2004). With all of these considerations in mind, to get an accurate picture of the role NIPFs will play in future biofuels market we must understand how these values influence the land management decisions of the landowners.

Much of the forest biomass harvested in the U.S. comes from private lands. Since the 1950's greater than 50\% of U.S. timber harvests are from NIPFs (Adams et al. 2006). One of the major risks associated with reliance on NIPFs to supply large amounts of biofuels feedstock stems from changes in ownership (Germain et al. 2007). Changes in ownership can lead to increased parcelization which may jeopardize both the quality and the quantity of the wood supply (Germain et al. 2007; Zhang et al. 2005; Butler 2008). Parcelization of forestlands decreases the efficacy of sustainable forest management plans due to smaller management area size, and the resultant lower economies of scale (Germain et al. 2007). It is estimated that $23 \%$ of NIPF acres in the U.S. will be sold within the next five years (Butler 2008). Over time the average size of a NIPF holding has decreased (Birch 1994; Zhang et al. 2005; Butler 2008). From 1994-2008 the average size of a NIPF holding in the U.S. decreased from 75 to 25 acres (Birch 1994; 
Butler 2008). As changes in ownership and parcelization continue, fewer NIPF acres will have timber harvesting goals (Germain et al. 2007). An additional concern is that decreased land holding size will lead to not only less acres as a working forest but also an overall decreasing timber supply (Zhang et al. 2005).

\section{Managing for Fuel and Biodiversity}

Biofuels and biodiversity can go hand in hand if the biofuel production does not lead to increased agricultural impacts or expand conversion of land from diverse habitat to monoculture (Groom et al. 2008).

Switchgrass is one of the principle crops being developed for the production of cellulosic ethanol (McLaughlin and Kszos 2005). A switchgrass monoculture is classified as a high input low diversity (HI-LD) ecosystem (Flaspohler et al. 2009). In order to achieve the high biofuels production goal while protecting biodiversity, low input high diversity (LI-HD) systems of production that are not monocultures will be necessary. These systems of production would include polyculture fields as well as native assemblages of prairie grasses (Flaspohler et al. 2009). These systems have the potential to produce large amounts of biomass while also providing a high degree of ecosystem heterogeneity, which is essential to maintaining high levels of biodiversity (Flaspohler et al. 2009; Groom et al. 2008).

Forest managers can choose to manage their forests along a continuum that stretches from a single species such as a poplar plantation to a forest ecosystem rich in species diversity and structure such as an old-growth forest. While poplar plantations grow rapidly and can be harvested on a schedule of short rotations they are less diverse 
than natural forest ecosystems (Christian et al. 1997). However, a poplar plantation can enhance biodiversity when planted on clearcut land (Groom et al. 2008). In general, as with other ecosystems, as the amount of heterogeneity in a forest stand increases the number of species in that stand also increases. One way to increase the heterogeneity of forested areas is to retain legacy trees during harvesting. These trees, which are typically large conifers or hardwoods, can provide the ecosystem variation necessary for a variety of bird and mammal species (Flaspohler et al. 2009).

While it is important to recognize that plantation forests may reduce species diversity on a stand level, the same is not necessarily true at the landscape level. At the larger landscape level the presence of tree plantations may act to increase overall diversity (Carnus et al. 2006). Plantation forests that are less diverse than naturally regenerated stands oftentimes can increase wildlife diversity at larger landscape levels (Carnus et al. 2006). Another argument can be made that plantation forests act to reduce the harvesting pressure on more species diverse natural forests. This is due to the ability to produce larger quantities of wood from smaller land area using plantation forestry (Sedjo and Botkin 1997)

Temporal considerations should also be taken into account when harvesting biomass (Flaspohler et al. 2009). For example, the best time to harvest trees in Michigan while protecting bird populations is to harvest outside of the primary nesting season (Flaspohler et al. 2009). If harvesting is done at the right time of year it can minimize biodiversity impacts while still providing biofuel feedstock. 


\section{Wildlife management on private lands}

Over the past 60 years there has been a drastic shift in how the American public values wildlife. Traditionally, American society tended to value the usefulness of wildlife for people. Today the public holds a more ecosystem based view which emphasizes nontraditional values such as the importance of wildlife conservation (Manfredo et al. 2003; Tarrant et al. 1997; Butler 2008). Although there has been a shift towards non-consumptive uses of wildlife it is important to understand that people value wildlife in very different ways.

While it is clear that wildlife values of American society are changing we must also ask, "Why are wildlife values changing?" Research suggests that America's increasing affluence, education, and urbanization are the main forces leading to a shift in values (Manfredo et. al. 2003). Another reason for shifting wildlife values stems from individual awareness of environmental problems. When an individual is aware about an environmental issue or problem occurring in their area and the problem is linked to individual behavior, people are more likely to act in a manner that would help alleviate the problem (Raedeke et al. 2001). In the context of wildlife, people are more likely to participate in ecosystem management activities which benefit wildlife or the associated habitat on their land if they understand how those actions can contribute to the alleviation of the ecological/wildlife problem (Raedeke et al. 2001). As wildlife values and beliefs shift away from traditional consumptive uses, there tends to be a change in the land management behaviors of private land owners.

Wildlife managers need to understand public wildlife values in order to enact effective policies that can achieve the goals of the wider public. This is because: (1) 
wildlife agencies are legally mandated to involve the public in the decision-making process; (2) attitudes predispose behavior (such as generating support for wildlife species protection); (3) a changing and diverse wildlife constituency has made it increasingly difficult to predict human responses to management actions; and (4) managing fish and wildlife on an ecosystem basis requires that human dimensions (including public attitudes and values) are considered (Tarrant et al. 1997). Once wildlife professionals and policymakers have an improved understanding of these values, attitudes, and behaviors they can address landowner concerns by creating incentive programs that appeal to owners and encourage better stewardship of their land (Belin et al. 2005).

Landowners can do many things to increase the appeal of their land to wildlife. For example, they can encourage forest understory growth thereby increasing the vertical heterogeneity of the forest and consequently increasing overall biodiversity (Bottoroff 2007; Sargent and Carter 1999). They can leave woody debris on the forest floor which provides shelter for small mammals, birds, and other wildlife. They can retain dead standing trees, also known as snags. These provide a source of food for many animals such as woodpeckers (Bottoroff 2007; Sargent and Carter 1999). These techniques can be compatible with timber harvesting. They can be incorporated into any silvicultural prescription. In this way a landowner may be able to achieve multiple land management objectives simultaneously (Bottoroff 2007).

One goal that is widely accepted among the public is to protect biodiversity (Birch 1994; Butler 2008). However, biodiversity protection is difficult to achieve via an ecosystem based approach in areas of numerous private ownerships, such as the Northeastern U.S. (Campbell and Kittredge 1996). It requires the management of an 
individual forest parcel or stand within the context of the larger landscape. The presence of more owners means the consideration of a wider range of individual goals and concerns (Campbell and Kittredge 1996). This approach is much more likely to succeed when it is encouraged through the use of incentives and outreach programs. Incentives are important because the diversity of values held by landowners makes it highly unlikely that landscape management goals will be achieved if everyone is concerned only about their own land. In addition, the use of regulation can discourage participation by individuals who place high value on property rights (Campbell and Kittredge 1996). In a study of cooperation between landowners in Western Massachusetts the use of costsharing incentives, education, and spatial information via GIS made landowners more aware of the mutual benefits that can be attained via cooperative land management planning (Campbell and Kittredge 1996).

\section{Gaps in literature}

Much is known from the literature about the values of NIPF owners. These values include such things as the protection of wildlife habitat, availability of outdoor recreation opportunities, improved timber quality, protection of private property rights, and aesthetics (Campbell and Kittredge 1996; Manfredo et al. 2003; Butler 2008). My work will expand our understanding of the values and motivations of private landowners.

Non-industrial private forestlands will contribute feedstock to a future cellulosic ethanol industry. For a number of reasons, determining how much biomass we can expect to harvest from NIPF for ethanol production on an annual basis is a difficult and important problem to address. Access to a sustainable reliable supply of fuel is vital to 
any energy industry, cellulosic ethanol included. My work will focus on how perceptions of wildlife, energy independence, global climate change, and land management values may affect land management decisions made by private landowners of Michigan's eastern Upper Peninsula.

Furthermore, I was unable to find any published work which examined whether eastern Upper Peninsula of Michigan landowners understand woody bioenergy/cellulosic ethanol markets. In addition, I could not locate any published work which attempts to determine if eastern Upper Peninsula landowners are interested in potentially participating in bioenergy markets, and what factors may influence their willingness to participate. These are two questions that my work will address. 


\section{Chapter 4: Research Design}

The main goal of my research is to determine how landowner values and beliefs, on a variety of issues including wildlife management, land management, and climate change, are expressed though their management decisions. Second, I aim to determine what factors motivate landowners to use or not use their land for the production of biofuels feedstock. Third, I aim to determine how landowner desires to protect biodiversity and wildlife habitat affects their decision to harvest timber products on their land. In addition, I will look at the type of harvesting these landowners would support. Finally, once I understand what influences landowners to make the land-use decisions they do, I hope determine some potential policies or recommendations which could potentially encourage landowners to use their land in a sustainable fashion for both the production of biofuels feedstock, as well as the protection of the region's biodiversity. In order to answer these questions, semi-structured interviews were conducted.

Before any interviews were conducted a randomized sample of landowners from the six eastern most counties in the Upper Peninsula of Michigan was generated. This allowed us to contact them about the project and solicit their participation. The rules that were used for the randomized sampling protocol can be found in Appendix A. In order to determine how many letters to send to each county a combination of the total number of private landowners in the county and the total timberland was taken into account. This ensured that a county with larger acreages of timberland and a larger landowner population received a greater proportion of the letters than a county on the other end of the spectrum. Table 1: below summarizes how the number of letters sent was distributed among the six counties. 
Table 1: Response data for Eastern Upper Peninsula of Michigan

\begin{tabular}{|l|c|c|c|c|}
\hline County & Interviews & Letters Sent & Response Rate & Reside on Parcel \\
\hline Alger & 3 & 32 & $9.4 \%$ & 1 of 3 \\
\hline Chippewa & 13 & 55 & $23.6 \%$ & 3 of 12 \\
\hline Delta & 11 & 40 & $27.5 \%$ & 2 of 11 \\
\hline Luce & 7 & 23 & $30.4 \%$ & 4 of 7 \\
\hline Mackinac & 4 & 24 & $16.6 \%$ & 2 of 5 \\
\hline Schoolcraft & 4 & 20 & $20.0 \%$ & 1 of 4 \\
\hline & & & & 13 of 42 \\
\hline Totals & 42 & 194 & $21.6 \%$ & \\
\hline \multicolumn{5}{|l|}{} \\
\hline * This chart excludes letters that were undeliverable & \\
\hline$*$ Six additional pilot interviews were conducted in Houghton County, Michigan \\
\hline
\end{tabular}

The letter that was sent to prospective interviewees can be found in Appendix B. The letter introduced the project, briefly summarized the focus, and asked the landowner if they were willing to participate in the study. A self addressed stamped envelope was included, along with a response form (found in Appendix C) in order to increase the ease with which the landowner would be able to convey whether they were willing to participate in the study.

The returned envelopes contained information as to whether the landowner accepted or declined our invitation to participate in the research project. For those landowners who did not return the envelope we used internet websites such as whitepages.com to find as many publicly listed land-line phone numbers as possible. We then called these individuals three times in order or further attempt to solicit an interview. The distribution of calls were as such; one in the morning, one in the afternoon, and one 
in the evening. The intent of the distribution was to increase the likelihood of being able to reach the landowner.

In total, 48 individuals were interviewed for the research project. The original goal was to complete 50 interviews from the eastern Upper Peninsula of Michigan. The goal was set at 50 as part of the grant requirements under which this research was funded. These 50 (in conjunction with 50 from the northern Lower Peninsula of Michigan) were intended to answer questions about this population as well as to inform a more widely disseminated survey. We conducted 42 over the phone, in-depth, semi-structured interviews with landowners from the six easternmost counties in Michigan's Upper Peninsula. In addition, we conducted six in-person pilot interviews in Houghton County, Michigan. The pilot interviews were excluded from the calculation of the response rates because the sample population of the pilot interviews was not randomly generated. For all other analytical purposes of the study the pilot interviews are included. Refer back to Table 1 for the summary of the response rates for the six Eastern Upper Peninsula counties.

All of the interviews were recorded using recordmycalls.com. This is a website which records the phone conversation as an audio file, which can then be downloaded onto a computer. The interviews were all transcribed verbatim, in order to ensure the accuracy and integrity of the data. From there labels were inserted for all the interviews. An example of a label is I38Q7. This label tells the analyst that the section of text comes from Interview 38 and is a response to question 7. Inserting these labels allows the analyst to effectively separate all of the questions from each interview. In the end a file was created for each of the 28 questions. These files allow the analyst to quickly read all 
of the responses from every interview to a specific question. The responses were then coded and classified. This coding system allowed me to determine how many interviewees gave each particular response for various questions from the interviews.

The people we talked to were in general, a very educated group of individuals. Only two interviewees reported that they did not finish high school. The other 45 interviewees reported finishing high school. Many of the interviewees completed postsecondary educational degrees or programs. Nine individuals (19\%) stated they had completed specific trade programs (such as a master plumber license) or vocational programs in order to learn the necessary skills for particular careers. Three respondents reported completion of an Associate's degree. Twenty (42\%) interviewees reported completion of a Bachelor's degree. There were 10 (21\%) individuals who reported finishing a Master's degree. Lastly, we interviewed three individuals who have attained a Ph.D. In comparing the numbers from our study with Michigan it becomes apparent that our group of interviewees in general attained a higher educational status than the general Michigan population.

There are numerous implications of having a highly educated sample. Education and income often go hand in hand. Consequently, having a highly educated sample infers that our sample is also more affluent than average in the State of Michigan. Studies have shown that affluence influences such things as the willingness to harvest forest products. Landowners who rely on their land for economic considerations are less likely to consider the aesthetic or intrinsic value of wildlife (Daley et al. 2004). On the other hand landowners who are highly educated tend to be more interested in preservation and less interested in management/utilization (Joshi and Arano 2009; Manfredo et al. 2003). 
The most recent data in the National Woodland Owner Survey indicates that the size of land is an important factor in predicting whether or not the landowner is likely to harvest timber products from their land, have a written management plan, and have received forest management advice from professionals (Butler 2008). For this reason we specifically asked the interviewees how much land they owned in the eastern Upper Peninsula of Michigan. In looking at the size of the parcels owned by the interviewees, I found that the average size of their parcel was 133 acres. The sizes for the parcels ranged from a low of 20 acres to a high of 1000 acres. In total, the combined size of the parcels owned by all 48 respondents was 6,404 acres. Thirty-one (65\%) interviewees did not reside on their land in the Eastern Upper Peninsula of Michigan. It is known that landowners are more likely to harvest forest materials from land that is not their primary residence (Butler 2008).

Numerous incentive programs exist that provide various benefits to landowners. In Michigan, many of these programs aimed at nonindustrial private forestlands provide benefits to landowners such as cost-sharing, technical assistance, and tax breaks (PotterWitter 2005). In return landowners use their land to provide such things as improved wildlife habitat, endangered species protection, sustainable forest management, wetland restoration, and climate change mitigation. The protection of wildlife and the production of timber are likely to be an important consideration for many eastern Upper Peninsula landowners. Consequently, I was interested to know the extent of knowledge landowners had regarding the available incentive programs that could potentially provide assistance to them in these areas. 
In order to answer the questions about landowner values and beliefs regarding topics such as wildlife, bioenergy development and timber harvesting, I analyzed the following questions from the interviews:

Q10. Have you ever cut trees on your land?

[If yes] When did that happen? For what purpose?

Q11. Do you plan to cut trees in the future?

[If yes] Can you describe your plans? For what purpose, personal firewood or selling timber/pulp? How many acres? Would it be clearcut or selectively thinned?

Q16 Are you interested in managing for wildlife on your land?

[If yes] Do you feel you have a sense of things you could do on your land to attract wildlife or give them good habitat? Do you do this already? What do you do?

Q18. Are you familiar with any government programs that are available to help landowners manage for wildlife by improving habitats or restoring wetlands? [If yes] Which programs? Would you consider enrolling in one of these types of programs? Why or why not? [If no, explain that they exist]

Q19. Have you heard the phrase "energy independence"?

[If yes] What have you heard? What does it mean to you? Do you think it's an important goal? Why or why not?

Q20. Have you heard of the term woody "bioenergy"?

[If no, explain] It basically refers to energy produced from plant materials, such as trees, grasses, or corn. 
[If yes] How about woody biofuel or cellulosic ethanol? What have you heard?

Q21. There are several newer companies in the U.P. that use forest materials to produce energy, including a power plant in L'Anse, a couple of wood pellet manufacturers, and a facility in Kinross that will be producing cellulosic ethanol for cars. They might be interested in buying forest materials from landowners such as you to produce energy. Have you heard about these types of companies in our area?

[If yes] What have you heard?

Q22. Do you think you would be interested in cutting trees from your land to sell to these types of companies? Why or why not?

Q23. Some people are planting fast growing trees, such as poplar, or grasses like switchgrass, in order to produce fast growing material that could be used for bioenergy. Is this something that you think you would ever do? Why or why not?

Q24. What do you think of when you hear the terms "climate change" or "global warming"?

[If not clear] Do you think it's not happening, is part of natural cycles, or is caused by humans? Do you think it will be a problem?

The full set of interview questions can be found in Appendix D. In addition to these questions, I collected data on educational attainment and the acreage of the land owned by each interviewee. 
My results from this analysis highlights four areas: landowner harvesting past and future, wildlife management interests of private landowners, landowner values and beliefs regarding energy independence and climate change, and private landowners and bioenergy.

\section{Hypotheses}

Three hypotheses were tested:

1: Landowners who manage their land for wildlife are less likely to participate in cellulosic ethanol markets, than those who do not manage for wildlife.

2: Landowners who believe national energy independence is an important goal will be more likely to support domestic bioenergy development than those who do not.

3: Landowners who believe in anthropogenic climate change will be more likely to support cellulosic ethanol development than those who do not. 


\section{Chapter 5: Results}

The results for some questions have different numbers of interviewees. This reflects the fact that during some interviews a question may not have been asked or answered. If during the analysis a question was not asked or answered that interview was excluded from the count because in that situation the interviewee was considered a nonrespondent.

\section{Landowners and timber harvesting}

In order to gain a better understanding of landowners and their harvesting practices, they were asked about any past harvesting as well as any plans for future harvesting. Specifically, as it relates to the past we asked if they had harvested trees, when the harvest(s) occurred, and for what purpose.

Forty-four (92\%) interviewees reported past harvests. Only four people had never cut a tree on their property. However, considerable variation occurred with regard to when harvests were conducted. Twenty-one (47\%) interviewees reported that they only cut trees occasionally as desired, or they only cut dead and down trees as needed in order to keep the forest neat. Nine interviewees conducted harvests between five and ten years ago. Five reported harvesting in the previous five years. One interviewee harvested between 10-15 years ago. Four interviewees harvested 15-20 years ago. Four interviewees reported harvesting approximately every five to ten years as the desired trees matured. 
Income was the most commonly stated reason for harvesting trees. Table 2 below summarizes the most common responses for harvesting timber. Twenty-six (54\%) interviewees reported harvesting trees for money. The next most common response

\begin{tabular}{|l|c|c|}
\hline \multicolumn{3}{|c|}{ Table 2: Most common reasons for harvesting timber } \\
\hline Reason & Responses & $\%$ response \\
\hline Income & 26 & $54 \%$ \\
\hline Personal Firewood & 21 & $47 \%$ \\
\hline Timber Stand Improvement & 12 & $25 \%$ \\
\hline Improve wildlife Habitat & 7 & $15 \%$ \\
\hline Personal building supplies & 6 & $12 \%$ \\
\hline
\end{tabular}

given for harvesting, was personal firewood consumption. Twenty-one (47\%) interviewees stated firewood as one of the reasons they harvested trees from their land. It is important to note that many of the individuals that harvested trees had multiple objectives for their harvest. Some conducted a harvest for both financial gain and to improve wildlife habitat. Others conducted a harvest for financial gain and then used all the tops and limbs for personal firewood. In fact, 13 individuals stated that one of the primary reasons for choosing a selection cutting method was to thin out the forest, and thus encourage the remaining trees to mature with the overall result be an improved timber stand. Seven interviewees stated that one of the goals of their harvest was to open up new growth and improve deer and other wildlife habitat in addition to financial gain. In addition to learning about past harvesting practices, we wanted to know what landowners planned regarding future harvests. We asked them if they planned to cut trees in the future, as well as asking them to describe their plans, what the purpose of the harvest would be, and what cutting methods they would use. 
There was a virtual even split in terms of landowners who had definite plans for harvesting in the future and landowners who did not have any specific plans for harvesting in the future. Twenty-two (49\%) interviewees reported that they plan to cut trees in the future, while twenty (44\%) interviewees stated that they had no definite plans to harvest timber from their land in the future. The remaining three interviewees stated that they probably would in the future but did not have definite plans to do so. Grouping those three respondents with the landowners who planned to harvest, increases the total number of interviewees who are likely to harvest in the future to $25(56 \%)$. When asked for what purpose the cuts would be done, twenty (80\%) interviewees reported they would sell the timber. Eleven (44\%) interviewees reported that they would periodically select cut their timber as it matures. Of the 21 landowners who reported harvesting firewood from their land, only four (19\%) stated that they planned to harvest firewood in the future.

Table 3 shows the distance each of the six eastern Upper Peninsula of Michigan counties is from the proposed cellulosic ethanol plant in Kinross. Distances were estimated from the center of the county to the proposed facility. Distance seemed to exert very little influence on whether or not interviewees were familiar with the proposed cellulosic ethanol plant. As you can see in Table 3, Chippewa County had the lowest percentage of interviewees that had heard of the plant, and that is surprising considering Chippewa County is the county in which the plant will be located. 


\begin{tabular}{|c|c|c|c|c|c|}
\hline County & $\begin{array}{c}\text { Distance from } \\
\text { Kinross } \\
\text { (miles) }\end{array}$ & $\begin{array}{l}\text { Number of } \\
\text { Interviews }\end{array}$ & $\begin{array}{l}\text { Have } \\
\text { heard } \\
\text { of CE } \\
\text { Plant }\end{array}$ & $\begin{array}{c}\text { Have } \\
\text { not } \\
\text { heard }\end{array}$ & $\begin{array}{c}\text { \% heard } \\
\text { of CE Plant }\end{array}$ \\
\hline Alger & 125 & 3 & 3 & 0 & $100 \%$ \\
\hline Chippewa & 0 & 13 & 9 & 4 & $69 \%$ \\
\hline Delta & 125 & 11 & 8 & 3 & $73 \%$ \\
\hline Luce & 25 & 7 & 5 & 2 & $71 \%$ \\
\hline Mackinac & 30 & 4 & 4 & 0 & $100 \%$ \\
\hline Schoolcraft & 100 & 3 & 3 & 0 & $100 \%$ \\
\hline Totals & & 41 & 32 & 9 & $78 \%$ \\
\hline
\end{tabular}

Another potential influence on whether or not non-industrial private forest owners would be willing to harvest timber and sell it to a bioenergy facility could be distance they are located to the facility. There could be numerous factors such as a desire to support the local industry or ability to get better prices for the timber due to lower transportation cost to the plant. Table 4, summarizes the willingness to harvest for bioenergy and proximity to the Kinross cellulosic ethanol facility. Distance does not seem to be a major factor in willingness to harvest for bioenergy among the sample population. There is not a readily discernable pattern among the counties. The county whose interviewees were least likely to harvest timber for bioenergy is Chippewa County where the plant will be located. However, all interviewees from Mackinac County which is adjacent to Chippewa County were willing to harvest for bioenergy. 


\begin{tabular}{|c|c|c|c|c|c|}
\hline County & $\begin{array}{l}\text { Distance } \\
\text { from } \\
\text { Kinross } \\
\text { (miles) }\end{array}$ & $\begin{array}{l}\text { Number of } \\
\text { Interviews }\end{array}$ & $\begin{array}{l}\text { Willing } \\
\text { to } \\
\text { Harvest }\end{array}$ & $\begin{array}{c}\text { Not } \\
\text { Willing } \\
\text { to } \\
\text { Harvest }\end{array}$ & $\begin{array}{l}\% \text { Willing } \\
\text { to Harvest }\end{array}$ \\
\hline Alger & 125 & 3 & 3 & 0 & $100 \%$ \\
\hline Chippewa & 0 & 13 & 7 & 6 & $54 \%$ \\
\hline Delta & 125 & 11 & 8 & 3 & $73 \%$ \\
\hline Luce & 25 & 7 & 7 & 0 & $100 \%$ \\
\hline Mackinac & 30 & 4 & 4 & 0 & $100 \%$ \\
\hline Schoolcraft & 100 & 3 & 2 & 1 & $67 \%$ \\
\hline Totals & & 41 & 31 & 10 & $76 \%$ \\
\hline \multicolumn{6}{|c|}{$\begin{array}{l}* \text { Distance approximated from center of county to Kinross } \\
* \text { Interview } 30 \text { not included due to question not being asked } \\
* \text { Pilot interviews were from distance comparison }\end{array}$} \\
\hline
\end{tabular}

\section{Wildlife management interests of private landowners}

A potentially major influence on the ability to develop a bioenergy industry in the Upper Peninsula of Michigan is the concern that landowners have for the health of wildlife populations, including both game and non-game species. In order to gain a better understanding of how Eastern Upper Peninsula landowners consider wildlife, we asked them if they are interested in managing their land for the benefit of wildlife and if they are, what they are planning to do or what are they currently doing in order to benefit wildlife populations and/or increase biodiversity.

We found a large percentage of landowners actively managed their land for the benefit of wildlife. Thirty four people (72\%) stated that they either manage for game species, biodiversity, or both. Here a landowner who was enthusiastic about using their land for both game and non-game species talks about what they had done: 
I have planted small food plots for deer. I have planted autumn olive for birds and grouse, and I've planted several years in a row seedlings of pine and spruce to help block the view from the roads... I have a pond in progress. I dug the hole some time ago and I just got a liner a couple weeks ago, to attract animals, birds, maybe waterfowl. I'm about a mile from Lake Michigan and there are no creeks real close, so this would be good for animals to drink so they don't have to go far...(Interview 13).

A different perspective on what is best for wildlife was discussed by four interviewees, who expressed the belief that allowing nature to take its course provided the greatest benefit to wildlife. An example of this belief in nature taking its own course can be seen in the following quote:

I think first and foremost is preservation of the land, because it's, to me especially, it's a resource, and it has very high sentimental value. I can't see that there would be any type of - I would never consider any type of commercial management of any type, you know what I mean, where somebody might come in and say, hey, you know what? You may wanna take this area out and food plot it for animals - we allow the animals to come and go as they want, which is nature's way, we do nothing to entice them other than leave the land as it is, and it has the natural food, natural cover, things of that nature. So there's no pressure our land (Interview 8).

When asked what they do to benefit wildlife, interviewees gave a wide variety of responses. Table 5 below summarizes the responses. Twenty people (43\%) stated that they have or will provide food plots of such plants as clover, rye, winter wheat, and buckwheat in order to benefit game species such as deer. Fifteen $(32 \%)$ said they planted or worked to protect berry bushes, shrubs, fruit trees, and other sources of wild food which they deemed to be beneficial to a variety of wildlife. Nine (19\%) stated that they 
put out food such as bird feed in order to attract and benefit wildlife. Seven (15\%) stated that they have installed or are in the process of having a wildlife pond installed.

\begin{tabular}{|l|c|c|}
\hline \multicolumn{3}{|c|}{ Table 5: Wildlife Management activities of landowners } \\
\hline Management Activity & Responses & $\%$ Response \\
\hline Maintain food plots (clover, rye, etc) & 20 & $43 \%$ \\
\hline Protect natural food sources & 15 & $32 \%$ \\
\hline Directly feed wildlife & 9 & $19 \%$ \\
\hline Installed/maintain ponds & 5 & $13 \%$ \\
\hline Build brush piles & 4 & $11 \%$ \\
\hline
\end{tabular}

Five (13\%) stated that one of the main goals of their completed commercial harvests is to improve wildlife habitat. Additionally, four (11\%) people actively maintained brush piles and logging slash in order to provide shelter for wildlife.

In order to evaluate knowledge of state and federal landowner incentive programs that could potentially help landowners attain their wildlife management goals, we asked them about their familiarity with various state and federal wildlife management programs. In addition to asking if they knew the programs existed, we also asked them to discuss specific programs they had knowledge about.

Very few interviewees possessed knowledge of the main federal and state wildlife management programs such as the Wildlife Habitat Incentive Program, the Michigan Landowner Incentive Program, the Safe Harbor Program, and the Wetlands Reserve Program. Nineteen (40\%) said they knew wildlife programs existed but did not know any specifics about the programs. Sixteen (34\%) stated that they were aware of some of the programs that currently exist. However, when pressed for more information about the programs only one of the interviewees mentioned a state or federal wildlife program.

The only federally administered wildlife program mentioned by an interviewee is the 
Wetland Reserve Program run through the Department of Agriculture's Natural

Resources Conservation Service, and it was mentioned once. The program provides cost sharing for landowners installing a pond for wildlife. The most frequently mentioned program was Michigan's Commercial Forest Act tax incentive program, which was mentioned 5 times (10\%). Other programs mentioned include programs run through Ducks Unlimited (2 or 4\%) as well as The Turkey Foundation (1 or 2\%). The Conservation Reserve Program was mentioned once (2\%). Lastly, 12 (26\%) stated they did not know government wildlife programs existed.

Once we had discussed wildlife management programs with the landowners, we wanted to gauge their interest in participating in one of the programs. We also wanted to know why they would or would not consider enrolling in any of the various wildlife management programs.

There was quite a bit of interest among the landowners we interviewed to learn more about government run wildlife incentive programs. Many of the individuals interested in learning more stated that they would consider enrolling their property in a wildlife program. A good example of this sentiment is summed up nicely in the following:

Oh, sure. I would consider it. If it sounds like something that makes sense at all. My wife is really interested in wildlife. She likes seeing and viewing animals. We've talked about different things we could do. It seems like time up there is kind of valuable for us and we can only do so much (Interview 4). 
Twenty-six (55\%) interviewees said they would consider enrollment, and/or were interested in learning more about the wildlife programs. There was also one interviewee who is currently enrolled in a conservation easement through Ducks Unlimited. The most common reason given for not considering enrollment in a wildlife management program is an infringement on private property rights that is assumed to occur if you use any federal or state wildlife incentive program. Nine (19\%) interviewees fell into this category. An example of this belief is shown in the following quote:

I think, you know, I have heard of some of those. But I think - this is just my philosophy on this... and my opinion is that anytime the government gets their hands into private property under the guise of being there for beneficial purposes, it gives them a source of unique control over that property, and I think, I just think down the road in the future it leads to basically the government dictating what you will and will not do with the property, and I don't believe in that (Interview 7).

In total, 21 (45\%) interviewees, for a number of reasons including private property, a lack of time, unable to gain consensus between multiple owners, a general lack of interest, and the desire to keep management decisions within the family stated that they are unwilling to consider enrolling in a wildlife management program.

\section{Landowner values and beliefs regarding energy independence and climate change}

In an effort to gain an understanding of how various environmental values and beliefs may affect the willingness of landowners to support bioenergy/cellulosic ethanol development, we asked them questions about the environmental/political topic of United States energy independence. We asked the respondents what the phrase, "energy independence" meant to them. Following that up, we asked whether they thought energy 
independence is an important national goal. Furthermore, we asked them why they felt energy independence was or was not an important national goal.

All but one interviewee stated the importance of energy independence as a national goal, although there were numerous thoughts as to why it was an important goal. Interviewees mentioned that for reasons including national and economic security, as well as environmental improvement, the United States should concentrate more on utilizing domestic sources of energy. Here is an example of a landowner's thought of national energy independence:

To me it means that the United States is able to have its own source of energy to drive its industry and heat its homes without having to depend on foreign sources for our energy.... Look at the costs. There are all kinds of costs. Right now we are having to send American lives over there and they are not coming all back so there is a cost to that. It's not that I am opposed to that effort but it would certainly be nice if we didn't have to depend on others for our source of energy. And utilize, we have so many sources here that we are just not doing enough to capitalize and use them (Pilot Interview 5)

On a whole 37 individuals (80\%) stated that they were familiar with the phrase, "energy independence". The other nine individuals (20\%) were not familiar with the term. Of the 37 interviewees who had an understanding of energy independence, 30 stated that it primarily means to be free of foreign oil and other sources of energy. However, when asked about what it means to them, people mentioned independence on multiple levels, including personal independence, municipal independence, all the way up to national independence. When discussing national energy independence the two primary reasons given for the importance of energy independence were economic reasons 
(10 people, $29 \%$ ) as well as national security reasons (six people, 17\%). In addition, seven (20\%) stated that, "Yes it is an important goal," but gave no specific reason.

The second major environmental issue we asked people about is the issue of climate change. We asked what people think of when they hear the phrase "climate change" or "global warming". In addition, we asked if they believed climate change is a naturally occurring phenomenon or if it is being influenced by human activity. We also asked what the landowner thought the prognosis was for the future health of the planet, in terms of the perceived positive or negative impacts associated with climate change.

There were significant numbers of interviewees who professed strong beliefs regarding anthropogenic climate change. Twenty interviewees (42\%) stated the belief that climate change is happening, humans are affecting it, and it will be a serious problem for society to deal with. Here is an example of a landowner expressing the belief that humans are having an impact on Earth's climate:

I think we are in big trouble. That is what I think. If the polar ice cap is disappearing so fast that countries are fighting over the ability to ship across the top of the world essentially, it is kind of like duh!, we got climate change (Interview 10).

The opposite opinion was expressed by 16 interviewees (33\%) who either did not believe that climate change is happening or did not think that humans have anything to do with influencing climate change. A landowner's disbelief in the concept of anthropogenic global climate change can be summed up effectively by one individual who said, "Well, they should have been around here last year when we had 250 inches of 
snow and two weeks of subzero weather. Where is the global warming? I think it is a crock of shit. Sorry (Interview 5)."

A final belief regarding climate change was expressed by 12 interviewees $(25 \%)$ who said they were aware of the issue but that they did not possess enough knowledge to be able to confidently state their opinion either way. Here an interviewer expresses the confusion and lack of understanding typical to this group of interviewees:

I am actually really confused about that, because I understand something is going on but like for us this year in Michigan we have had a really cool summer and a wet one down here. I understand the scientists all say that is part of global warming and stuff because there are other parts of the world that are really hot. Most people that I hang out with we are not sure if it is really happening or if it is a continuous world thing that happens every so often anyhow like you know we've had ice ages before and stuff like that (Interview 1).

Figure 2 shows their beliefs regarding climate change. Most believed

\section{Figure 2: Interviewee Beliefs Regarding Anthropogenic Climate Change}

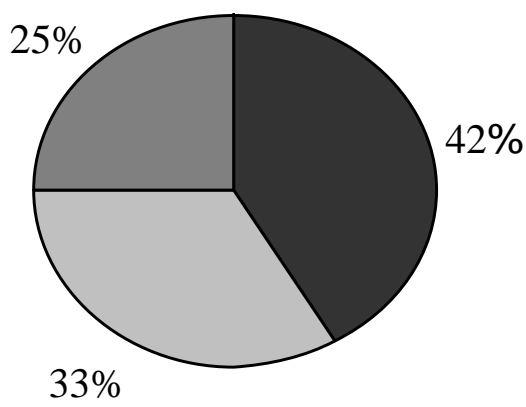

Believe in Anthropogenic Climate Change

$\square$ Do Not Believe in Anthropogenic Climate Change

$\square$ Unsure/Lack of Knowledge 
humans are influencing the climate of Earth. One-third do not believe humans

have any influence on Earth's climate. Lastly, one-quarter felt they lacked

sufficient knowledge to make an informed decision either way.

\section{Private landowners and bioenergy}

In the section of the interview centered on bioenergy development, respondents were asked a series of questions. The first couple of questions were designed to gain an understanding of the depth of knowledge the interviewee had pertaining to both woody bioenergy and more specifically, cellulosic ethanol. Once asked about whether they had heard of woody bioenergy and cellulosic ethanol, the interviewees were asked a follow up, which was to state what they had heard or understood about these types of bioenergy.

Thirty $(63 \%)$ interviewees had at least an elementary understanding of woody bioenergy. Thirty two (66\%) had at least an elementary understanding of cellulosic ethanol. There were a wide variety of responses in regards to what individuals had heard/understood in regards to woody bioenergy and cellulosic ethanol. Of the 32 who stated they had heard of cellulosic ethanol, $19(60 \%)$ possessed a basic understanding of the process of converting biomass (some stated switchgrass or trees or vegetation) into ethanol. For example, a landowner with an understanding of cellulosic ethanol processing said, "Well my understanding is that they would take biomass, woody plants and vegetation and whatever and convert it to ethanol for fuel to fuel cars and whateverol (Interview 2)."

When asked to describe their understanding of cellulosic ethanol, interviewee responses were varied and diverse. Other than the eight interviewees who discussed their 
awareness of the commercial cellulosic ethanol facility proposed for Kinross, Michigan, the remaining responses were made by only one or two people, and had no discernable pattern. These interviewees talked about some of the negative and positive aspects associated with bioenergy development. Some of the issues raised included the exorbitant amount of wood that would be needed, the difficulty of producing the ethanol in an economically efficient manner, the expected increase in stumpage prices, and that it would likely take longer than expected to get the facility up and running due to the extensive amount of red tape. Others talked more positively about the developments such as the expected boost to the local forest products industry and the social and environmental benefits of cellulosic ethanol as opposed to corn ethanol.

Once the questions which centered on landowner bioenergy understanding were completed, interviewees were asked if they had heard of or were aware of the various bioenergy companies in the Upper Peninsula. These bioenergy companies were either currently operating or were in early developmental stages. The companies listed in the question included Mascoma Corporation's proposed cellulosic ethanol plant in Kinross, a biomass power plant currently operating in L'anse, as well as some wood pellet manufacturers. In a follow up to the question asking if they had heard of these companies, interviewees were asked to specifically explain what they had heard or what they understood in regards to these companies and their activities.

Thirty four (77\%) interviewees reported they were familiar with at least one of the bioenergy facilities in the Upper Peninsula. The majority of those 34 respondents (28 people, $82 \%$ ) specifically referenced the cellulosic ethanol plant proposed for Kinross. 
Here a landowner discusses the proposed bioenergy developments in the Upper Peninsula:

Yeah, we've been paying attention because of course, my dad is a logger. And now see, I think personally this is the way to go. You're not raising the prices of food in order to produce, but yet you're still turning away from the foreign supplies. But now I have to say that my dad thinks it's really going to raise stumpage prices. And because of that, he thinks that there may be some issues down the road that we're not expecting. Right away, I thought he's going to have contracts to fill; this is going to be good. But he's doubtful. I think it's a great idea too, but he's concerned about how it's implemented (Interview 20).

Of those 28 individuals who had heard of the Kinross facility, $14(50 \%)$ were unable to further elaborate on what they had heard. The remaining 14 had a basic understanding that the plant would be using trees to produce ethanol.

The next step in the process was to determine how or if the biomass harvesting plans of the landowners could potentially include these bioenergy companies. Specifically, they were asked if they would be willing to sell trees which had been cut from their land to these types of bioenergy companies. In addition, we asked the landowners why they would or would not be willing to harvest trees from their land for bioenergy production.

A considerable amount of private landowners mentioned that if they were to harvest wood from their land they would be willing to sell the materials to a bioenergy company. Twenty nine (63\%) people stated they would be willing to sell to a bioenergy company, while an additional five stated they would be willing under certain circumstances. In total that accounted for $74 \%$ of the interviewees. Here is an example 
of someone who would likely be willing to participate in the provision of bioenergy feedstock from their land:

Yeah, I would do it on kind of a...I wouldn't go clearing areas out, but I'm quite certain that it could be done on kind of a select-cut basis. I know not on an every-year kind of basis, but rather every so often, clearing some areas out helps the wildlife habitat and it needs to be done (Interview 6).

The remaining 12 (26\%) interviewees said they would not be willing to sell timber from their land.

When asked to state why they would or would not be willing to sell trees to a bioenergy company there were many different responses. The most common response, which was made by $14(32 \%)$ interviewees, was that they would be willing to sell as long as the prices were competitive with the timber market as a whole. If the bioenergy company was not willing to pay top dollar price they would prefer to sell their timber elsewhere. Other common responses generally revolved around the type of cutting that would be permitted. Twelve (27\%) stated they would not allow any clear-cutting and any harvesting that would be done for bioenergy would have to be done in a scaled-back selective manner.

The last question in the bioenergy section focused on the idea of planting and maintaining energy crops. Interviewees were asked if planting fast growing trees such as poplar, or grasses such as switchgrass is something that could potentially fit in with their land management goals and objectives. In order to further explore landowner values and beliefs regarding energy cropping on their property for bioenergy purposes, we asked the landowners why they would or would not be willing to plant energy crops on their land. 
Nineteen $(50 \%)$ people said they would not be willing to grow dedicated energy crops. For example, when asked whether they would consider growing energy crops one interviewee said, 'I don't really think so. I don't have any land that's vacant...Yeah, it's all woods except for the one spot where the house is. And so I wouldn't be able to consider it (Interview 9)."

Ten (26\%) stated they would be willing to grow dedicated energy crops if there was a market for the materials, but that until such a market materializes they would not plant them. For example one said when asked whether they would be willing to plant energy crops:

Oh sure, yeah...Because it falls right in line with my objectives. You know, keeping land from being parceled off, and making it self-sustaining, where you could own land and not have to be digging into your pocket all the time to do that. And then having the joy of...I don't get excited about the idea of IRA's and things like that. I like retirement investments, so to speak, that I can play with too. For me, this is hands-on and I love being in the outdoors. You know, once in a while I'll do a little hunting...or just plain walking around on it and knowing that for a while, I'm in charge here. If that makes sense (Interview 4).

Eight $(21 \%)$ interviewees expressed some interest in the idea of energy cropping but seemed to be wavering on the fence as to whether they would or would not and could only state that it was a possibility. Of the individuals to whom we asked this question, there was an individual that was already growing a hybrid poplar with the sole intention of using it to produce bioenergy. In this case it was for heating his family's residence in the winter time. 


\section{Hypotheses}

$\mathbf{1}^{\text {st }}$ Hypothesis: Landowners who manage their land for wildlife are less likely to participate in cellulosic ethanol markets, than those who do not manage for wildlife.

This hypothesis was nullified, as I found that there was virtually no difference in willingness to participate in cellulosic ethanol markets between landowners who do or do not manage for wildlife. Table 6 , summarizes the findings:

\begin{tabular}{|c|c|c|}
\hline \multicolumn{3}{|c|}{ Table 6: Does managing for wildlife influence the provision of biomass } \\
feedstock? \\
\hline & Manage for wildlife & Do not manage for wildlife \\
\hline $\begin{array}{c}\text { Would sell biomass } \\
\text { for bioenergy }\end{array}$ & $66 \%$ & $65 \%$ \\
\hline $\begin{array}{c}\text { Would not sell } \\
\text { biomass for bioenergy }\end{array}$ & $25 \%$ & $29 \%$ \\
\hline
\end{tabular}

Looking at the table you can see the percentage of landowners in all categories is almost identical.

$2^{\text {nd }}$ Hypothesis: Landowners who believe national energy independence is an important goal will be more likely to support domestic bioenergy development than those who do not.

This hypothesis was difficult to compare because only one interviewee stated that national energy independence is not an important goal for the United States. A majority $(62 \%)$ of those who did believe it was an important goal stated they would be willing to supply biomass for bioenergy production. 
$\mathbf{3}^{\text {rd }}$ Hypothesis: Landowners who believe in anthropogenic climate change will be more likely to support cellulosic ethanol development than those who do not.

The data supports the hypothesis. Seventy-four percent of individuals who believe in anthropogenic climate change would be willing to supply bioenergy feedstock. Conversely, $56 \%$ of individuals who do not believe in anthropogenic climate change would be willing to supply bioenergy feedstock. 


\section{Chapter 6: Discussion}

The landowners from our study were much more likely to commercially harvest timber from their land than was expected. According to the National Woodland Owners Survey (NWOS), 21\% of private landowners (family owners) in Michigan have conducted a commercial timber sale on their property. In our study we found that fiftyfour percent $(\mathrm{N}=26)$ of interviewees had conducted a commercial timber sale on their property. The reasons given for harvesting were similar to those that were reported for Michigan in the National Woodland Owner Survey, which listed timber stand improvement, wood for personal use, improving wildlife habitat, and financial benefit as particularly important reasons to harvest.

Similar to the results for past harvesting, there was also a larger than expected amount of planning for future harvesting among our sample. It was expected that around 10 percent of owners would plan to commercially harvest in the future (Butler 2008). However, 44\% (20) of landowners in our study stated they planned to sell timber in the future.

There were a higher percentage of landowners from this study who had a professional written management plan than was expected from the literature (Butler 2008). According to the NWOS, in Michigan, about $3 \%$ of private landowners have a written management plan. Fifteen percent $(\mathrm{N}=7)$ of our sample reported having a written management plan.

Numerous studies have documented the importance of protecting wildlife and their associated habitats to private landowners (Butler 2008; Erickson et al. 2002; 
Manfredo et al. 2009). Our research supports those findings. Thirty-four (72\%) reported using their land for the benefit of games species, biodiversity, or both. In addition to those 34 people there were 4 individuals who expressed the belief that by doing nothing and letting nature take its course, they were doing what was best for wildlife.

Similar to what has been reported elsewhere, there was very little knowledge about government-run forest, wildlife management, and biodiversity conservation incentive programs for private landowners (Butler 2008; Jacobson 2009; Kilgore et al. 2007). Only one individual in our study was able to name and describe a wildlife incentive program. Although there was a great deal of interest in managing for wildlife, it was surprising that there was so little knowledge about these types of programs which are designed to ease the financial and technical burden on landowners. The most commonly stated reason to not participate in these types of programs is the perceived loss of private property rights. This supports other studies that have documented the sanctity of property rights to many landowners (Brunsun et al. 1996; Creighton et al. 2002; Daley et al. 2004; Mehmood and Zhang 2005). Many private landowners would not enter into a contract with the government concerning management of their land. However, our study as well as many others have found that most landowners, even those who are very leery of the government and who place enormous value on property rights are interested in education and technical assistance to help reach their management goals and objectives (Doremus 2003; Kilgore et al. 2007)

Interviewees' opinions about global climate change and its impacts seem to follow the trends we see nationally (Leiserowitz et al. 2010). These polls and our data similarly show about $40-50 \%$ believing in anthropogenic climate change. They show $30-$ 
$40 \%$ believing in natural causes of climate change. They also show about $10-20 \%$ unsure of what to believe due to a lack of knowledge of the subject.

Both the Democratic Party (www.democrats.org) and the Republican Party (www.gop.org) list "energy independence" as the top energy issue of their respective party's platform. Both parties consider it to be of paramount importance to the United States. Similarly our study found that virtually everyone who was familiar with the term believed it to be an important goal for our country. Only one interviewee did not perceive the pursuit of energy independence to be an important goal.

Seventy-four percent of landowners in this study would be willing to sell timber to a bioenergy company. All of those individuals, except one, who would support bioenergy development, also stated they believed that national energy independence is an important goal for the country. It is likely that a desire for not only energy independence but also to improve local economies, national security, and environmental improvements influence a landowner's support for cellulosic ethanol development. 


\section{Chapter 7: Conclusion}

\section{Bioenergy Development:}

The prospect for private landowner participation in the development of a bioenergy industry in the Eastern Upper Peninsula of Michigan is promising. Generally interviewees were knowledgeable about both cellulosic ethanol as well as the plans for the commercial facility proposed for Kinross, MI. In addition, many of the people we spoke to were supportive of the industry and would be potentially willing to sell harvested material from their land to the cellulosic ethanol facility.

Almost all biomass feedstock for the cellulosic ethanol facility coming from private lands will need to be harvested in a selective and sustainable manner. Landowners repeatedly said they were willing to participate in providing feedstock for biofuel production, but only if in doing so they were able to protect their other values. Some landowners talked about the need to protect habitat for white-tailed deer. Other landowners enjoyed the beauty of the forest and the opportunity to recreate in it. Other land owners used their land as a wildlife sanctuary. They were interested in doing things like thinning treatments for timber stand improvement, harvesting older mature trees, harvesting diseased trees such as beech or ash, and opening up the canopy to encourage the growth of a new cohort of trees, or to improve wildlife habitat.

In addition to harvesting woody biomass, there were numerous landowners who expressed interest in planting energy crops such as plantation forestry or switchgrass. However, they were quick to point out that in order to make the decision to begin planting energy crops, they need guarantees that the materials will be purchased by a 
bioenergy company. Some landowners stated that it would be necessary to have a longterm contract in place prior to the planting of any sort of energy crop. It is risky for landowners to plant energy crops without guarantees, especially for those landowners who depend on the economic benefits derived from the land. Consequently, a critical component to an upstart bioenergy company seeking to procure energy crops from private lands is to set up contracts of lengths approaching 10 years or more. Without these contracts it is unlikely that private landowners will plant dedicated bioenergy crops. A successful biofuel harvesting policy should remove the risk for planting from the farmer in order to increase the acreage of dedicated energy crops.

There is an opportunity to create an incentive program that incorporates multiple objectives, of which one is the provision of biomass for bioenergy production. The existing incentive programs relating to bioenergy production are generally focused on energy crops such as switchgrass or plantation willow. Other programs provide financial incentive to the company that is producing bioenergy. However, I am unaware of any program that combines bioenergy production and sustainable forestry for private landowners. The proposed incentive program could be successful if in addition to biomass harvesting it protected the other values of the landowner. If landowners were provided with financial assistance to manage their land for bioenergy and wildlife and in addition were provided informational and technical expertise about how to achieve their management goals, I think there would be interest among private landowners. However, as with other government landowner incentive programs a major obstacle to their success is making the public aware of the benefits such programs can provide. 
For all future or current incentive programs to be effective in reaching their stated goals the public must be made aware of their existence. Without knowledge of the benefits for themselves and their land, it is unlikely the program will ever enroll many acres of private land. The information about incentive programs is available though government websites as well as in other locations. However, it may be worthwhile to send information about these programs to landowners along with their property tax bills. I am unaware of any incentive programs in Michigan currently doing this. It could be a very effective time to solicit the public to enroll in incentive programs that provide tax breaks, considering that many people do not look forward to paying their property taxes. There should also be an emphasis on incentive programs that focus on the provision of information and technical assistance. These types of services are much more acceptable to a wide range of private landowners, especially, those landowners who place high value on private property rights.

\section{Potential Biases}

People who responded to our letter were much more interested in managing their land for a variety of purposes including timber, wildlife, recreation, and privacy than the average private landowner. They were much more likely to have commercially harvested their forest. They were also much more likely to have professional management plans for their property. These factors taken together could potentially lead to the wrong conclusion about the extent of interest expressed by private landowners for bioenergy development in the Eastern Upper Peninsula of Michigan. With 42 interviews and 194 letters sent the error rate for the study is 13.5 . 
Care must also be taken to recognize the very low response rate for the study. This level of response makes it intellectually dangerous to try and draw conclusions about the broader public. Part of the reason for the low response rate is the increasing reliance on cell phones. While it is straightforward to get mailing addresses for landowners, getting phone numbers that they can be reached at is entirely different. Only about half of our sample had publicly listed land-line telephone numbers. This was limiting because we were unable to follow-up with a series of telephone calls in a further attempt to solicit interviews. Approximately $15-20$ of the interviews that we conducted were the result of cold calling. If we would have had the opportunity to cold-call the remaining individuals in our sample, I am confident that we would have yielded another 15-20 interviews. The sample was not simply expanded as the original intent of the randomized sample was to have a high enough response rate to be able to draw conclusions about the study population. Furthermore, young people tend not to purchase landline phones and instead rely on cell phones. Consequently, reliance on land-line telephones potentially introduces age bias in the sample by excluding younger landowners.

\section{Future Research Avenues:}

It would be very valuable to build on this research by expanding the project into other areas surrounding the proposed site for the cellulosic ethanol facility. These areas include the Northern Lower Peninsula of Michigan as well as Ontario, Canada. A feasible distance for supplying biofuel feedstock to the plant is about 150 miles. Talking to landowners from everywhere within the 150 miles would be beneficial, as differences 
could exist between Canada, the Upper Peninsula of Michigan, and the Lower Peninsula of Michigan.

Another avenue of future study would be to interview three separate groups. All three groups would be private landowners. The first group would be composed of individuals who own forestland. The second group would be composed of people who own old abandoned fields, and the third group would be individuals who own agricultural lands. It could be useful to see what differences exist in regards to a willingness to both provide feedstock as well as produce energy crops.

It would also be of great benefit to use this data to design a survey. The survey could be much more broadly disseminated and would hopefully allow us to draw more accurate conclusions about what the general NIPF population believes and values in regards to bioenergy development in the eastern Upper Peninsula of Michigan. The survey would also provide a greater amount of quantitative data and would allow a researcher to look at a greater number of variables that influence landowner decision making. These could include ethnicity, gender, education, income levels, land tenure, political affiliation, and many more. 


\section{Final Word:}

It is essential that our country find a way to eliminate our dependence on fossil fuels for environmental, economic, and national security reasons. While biofuels alone do not provide the solution to complex problems such as climate change, they do have the potential to act as a bridge energy source to a clean renewable energy future, one which has much lower impacts on the environment and economy than fossil fuels. However, care must be taken in developing these industries. If we allow biodiversity and other values to suffer as a result of increased biofuel production it will be difficult to make the claim that biofuels are beneficial for society.

In spite of the problems with biofuels, some biofuels such as cellulosic ethanol have the potential to provide many environmental, social, and economic benefits and should be pursued in a sustainable manner as an alternative to gasoline. After talking with numerous landowners from across the Upper Peninsula, I feel confident that if they do decide to participate in the provision of cellulosic ethanol feedstock from private lands it will mostly be done in a sustainable manner. Most landowners will protect much of what makes the Upper Peninsula of Michigan a beautiful place to live. They will protect our air, water, wildlife, and outdoor recreation opportunities. 


\section{Literature Cited}

Adams, D.M., R.W. Haynes, and A.J. Daigneault. 2006. Estimated timber harvest by U.S. region and ownership, 1950-2002. Resource Bull. PNW-GTR-659, USDA For. Serv. Pacific Northwest Res. Stn., Portland, OR. 64p.

Baughman, M.J., J.C. Cervantes and D.M. Rathke. 1998. Reaching Minnesota's Nonindustrial Private Forest Owners. Paper presented at the conference Improving Forest Productivity for Timber: A Key to Sustainability. 1-3 December 1998, Duluth, MN.

Belin, D.L., D.B. Kittredge, T.H. Stevens, D.C. Dennis, C.M. Schweik, and B.J. Murzoch. 2005. Assessing Private Forest Owner Attitudes toward Ecosystem-Based Management. Journal of Forestry 103(1):28-35.

Birch, T.W. 1994. Private Forest Land Owners of the United States. USDA Forest Service Northeast Experiment Station Resource Bulletin NE-134.

Bottorff, J. 2007. Wildlife habitat management practices on private non-industrial forestlands 61-64. Harrington, B. T., and Nicholas, B. G. (Eds.) Managing for wildlife habitat in westside production forests. General Technical Report PNWGTR-695.

Brunson, M.W., D.T. Yarrow, S.D. Roberts, D.C. Guynn, and M.R. Kuhns. 1996. Nonindustrial private forest owners and ecosystem management: Can They Work Together? Journal of Forestry 94(6):14-21.

Butler, B.J. 2008. Family Forest Owners of the United States, 2006: A Technical Document Supporting the Forest Service 2010 RPA Assessment. U.S. Forest Service Publication June:1-74.

Butler, B. J., and Leatherberry, E. C. 2004. America's family forest owners. Journal of Forestry 102(7): 4-14. 
Butler, B. J., Tyrrell, M., Feinberg, G., VanManen, S., Wiseman, L., and Wallinger, S. 2007. Understanding and reaching family forest owners: Lessons from social marketing research. Journal of Forestry 105(7): 348-357.

Campbell, S. M., and Kittredge, D. B. 1996. Ecosystem-based management on multiple NIPF ownerships. Journal of Forestry 94(2): 24-29.

Carnus J-M, Parrotta J, BrockerhoV EG, Arbez M, Jactel H, Kremer A, Lamb D, O’Hara K, and Walters B 2006. Planted forests and biodiversity. Journal of Forestry 104(2): $65-77$.

Christian, D. P., Collins, P. T., Hanowski, J. M., and Niemi, G. J. 1997. Bird and small mammal use of short-rotation hybrid poplar plantations. Journal of Wildlife Management 61(1): 171-182.

Copulos, M.R. 2007. The Hidden Cost of Imported Oil - An Update. The National Defense Council Foundation, downloaded May 15, 2010 from www.ndcf.org.

Creighton, J. H., Baumgartner, D. M., and Blatner, K. A. 2002. Ecosystem management and nonindustrial private forest landowners in Washington State, USA. Small-scale Forest Economics, Management, and Policy 1(1): 55-69.

Dale, B. 2007. Grassoline in your tank. MSU Alumni Magazine: 18-22.

Daley, S. S., Cobb, D. T., Bromley, P. T., and Sorenson, C. E. 2004. Landowner attitudes regarding wildlife management on private land in North Carolina. Wildlife Society Bulletin 32(1): 209-219.

DiPardo J. 2004. Outlook for biomass ethanol production and demand. Energy Information Administration, US Department of Energy, Washington, D.C. Available at: http://tonto.eia.doe.gov/ftproot/features/biomass.pdf Accessed: May 15, 2010.

Doremus, H. 2003. A policy portfolio approach to biodiversity protection on private lands. Environmental Science \& Policy 6(3): 217-232. 
Energy Independence and Security Act of 2007. S. 201, $110^{\text {th }}$ Congress, $1^{\text {st }}$ Sessions (2007).

Erickson, D. L., Ryan, R. L., and Young, R. D. 2002. Woodlots in the rural landscape: landowner motivations and management attitudes in a Michigan (USA) case study. Landscape and Urban Planning 58: 101-112.

Farrell, A. E., Plevin, R. J., Turner, B. T., Jones, A. D., and O’Hare, M. 2006. Ethanol can contribute to energy and environmental goals. Science 311: 506-510.

Flaspohler, D. J., Webster, C. R., and Froese, R. E. 2009. Bioenergy, biomass, and biodiversity. In B. D. Solomon \& V. A. Luzadis (Eds.), Renewable energy from forest resources in the United States. New York: Routledge.

Germain, R. H., Anderson, N., and Bevilacqua, E. 2007. The effects of forestland parcelization and ownership transfers on nonindustrial private forestlands forest stocking in New York. Journal of Forestry 105(8): 403-408.

Giampietro, M., Ulgiati, S., and Pimentel, D. 1997. Feasibility of large-scale biofuel production. BioScience 47(9): 587-600.

Greene, N. 2004. Growing Energy: How biofuels can help end America's dependence. Natural Resources Defense Council. Available at: http://www.nrdc.org/air/biofuels/biofuels.pdf. Accessed August 15, 2010.

Greene, D. L., and Ahmad, S. 2005. Costs of U.S. Oil Dependence: 2005 Update. Available at: http://wwwcta.ornl.gov/cta/Publications/Reports/ORNL_TM2005_45.pdf Accessed August 15, 2010.

Greene, N., and Mugica, Y. 2005. Bringing biofuels to the pump: An aggressive plan for ending America's Oil Dependence. Natural Resources Defense Council. Available at: http://www.nrdc.org/air/energy/biofuels/contents.asp. Accessed August 15, 2010. 
Greer, D. 2005. Spinning straw into fuel. BioCycle 46(4): 61-66.

Groom, M.J., E.A. Gray, and P.A. Townsend. 2008. Biofuels and Biodiversity: Principles for promoting better biofuels policies. Conservation Biology 22(3): 602609.

Hill, J., Nelson, E., Tilman, D., Polasky, S., and Tiffany, D. 2006. Environmental, economic, and energetic costs and benefits of biodiesel and ethanol biofuels. Proceedings of the National Academy of Sciences of the United States of America, 103, 206-210.

Hodgdon, B. and Tyrrell, M. 2003, Literature Review: An Annotated Bibliography of the Published and Grey Literature on Family Forest Owners, GISF Research Paper 002, Global Institute of Sustainable Forestry, Yale University, New Haven, Available at: http://sustainingfamilyforests.org/pdf/litreview.pdf. Accessed May $15,2010$.

The IPCC 4th Assessment Report, Climate Change 2007: Synthesis Report. Contribution of Working Groups I, II and III to the Fourth Assessment Report of the Intergovernmental Panel on Climate Change, eds Team CW, Pauchauri RK, Reisinger A (IPCC, Geneva), $p 104$.

Jacobson, M. G., Straka, T. J., Greene, J. L., Kilgore, M. A., and Daniels, S. E. 2009. Financial Incentive Programs' Influence in Promoting Sustainable Forestry in the Northern Region. Northern Journal of Applied Forestry 26(2): 61-67.

Jones, Donald W.; Leiby, Paul N. and Paik, Inja K. 2004. Oil Price Shocks and the Macroeconomy: What Has Been Learned Since 1996? The Energy Journal 25(2), pp. 1-32.

Joshi, S., and Arano, K. G. 2009. Determinants of private forest management decisions: A study on West Virginia NIPF landowners. Forest Policy and Economics 11: 118125. 
Kilgore, M. A., Greene, J. L., Jacobson, M. G., Straka, T. J., and Daniels, S. E. 2007. The influence of financial incentive programs in promoting sustainable forestry on the nation's family forests. Journal of Forestry 105(4): 184-191.

Kim, H., Kim, S., and Dale, B. 2009. Biofuels, Land Use Change, and Greenhouse Gas Emissions: Some Unexplored Variables. Environmental Science and Technology 43(3): 961-967.

Lal, R., and Pimentel, D. 2007. Biofuels from crop residues. Soil and Tillage Research 93(2): 237-238.

Lave, L. B., Griffin, M. W., and Maclean, H. 2001. The ethanol answer to carbon emissions: When the United States gets serious about the threat of global climate change, it should turn to ethanol to power cars. Issues in Science and Technology, 18(2), 73-79.

Leiserowitz, A., Maibach, E., and Roser-Renouf, C. \& Smith, N. 2010. Global Warming's Six Americas. Yale University and George Mason University. New Haven, CT: Yale Project on Climate Change.

Lynd, L. R. 1996. Overview and evaluation of fuel ethanol production from cellulosic biomass: technology, economics, the environment, and policy. Annual Review of Energy and Environment 21: 403-465.

Lynd, L. R., Cushman, J. H., Nichols, R. J., and Wyman, C. E. 1991. Fuel ethanol from cellulosic biomass. Science 251: 1318-1326.

Lynd, L.R., Laser, M., McBride, J., Podkaminer, K., and Hannon, J. 2007. Energy myth three - High land requirements and an unfavorable energy balance preclude biomass ethanol from playing a large role in providing energy services. Invited chapter in: B. Sovacool and M. Brown (eds) Energy and American Society: Thirteen Myths Springer. 
Lynd, L. R., and Wang, M. Q. 2004. A product-nonspecific framework for evaluating the potential of biomass-based products to displace fossil fuels. Jounal of Industrial Ecology 7: 17-32.

Manfredo, M. J., Teel, T. L., and Bright, A. D. 2003. Why are public values toward wildlife changing? Human Dimensions of Wildlife 8: 287-306.

Manfredo, M. J., T. L. Teel, and K. L. Henry. 2009. Linking society and environment: a multi-level model of shifting wildlife value orientations in the western U.S. Social Science Quarterly 90: 407-427.

McLaughlin, S. B., Kiniry, J. R., Taliaferro, C. M., and Torre Ugarte, D. D. 2006. Projecting yield and utilization potential of switchgrass as an energy crop. Advances in Agronomy 90: 267-296.

McLaughlin, S. B., and Kszos, L. A. 2005. Development of switchgrass (Panicum virgatum) as a bioenergy feedstock in the United States. Biomass and Bioenergy 28: $515-535$.

Mehmood, S. R., and Zhang, D. 2005. Determinants of forest landowner participation in the Endangered Species Act Safe Harbor Program. Human Dimensions in Wildlife 10: $249-257$.

Michigan Department of Natural Resources. (n.d.). Michigan forest carbon program: Carbon Sequestration on Michigan Working Forest Lands. Retrieved May 12, 2010, from

http://www.michigan.gov/documents/dnr/CarbonSequestrationInMi_275110_7.pdf Michigan Department of Natural Resources. (2010). Overview Landowner Incentive Program. Retrieved May 12, 2010, from http://www.michigan.gov/dnr/0,1607,7153-10370_36649---,00.html 
Munsell, J. F., and Germain, R. H. 2007. Woody biomass energy: An opportunity for silviculture on nonindustrial private forestlands in New York. Journal of Forestry 105(8): 398-402.

Patzek, T. W., and Pimentel, D. 2005. Thermodynamics of energy production from biomass. Critical Reviews in Plant Sciences 24: 327-364.

Perlack, R. D., Wright, L. L., Turhollow, A. F., Graham, R. L., Stokes, B. J., and Erback, D. C. 2005. Biomass as feedstock for a bioenergy and bioproducts industry. United States Department of Energy \& United States Department of Agriculture. Available at:

http://feedstockreview.ornl.gov/pdf/billion_ton_vision.pdf. Accessed May 12, 2010.

Pimentel, D., and Patzek, T. W. 2005. Ethanol production using corn, switchgrass, and wood; biodiesel production using soybean and sunflower. Natural Resources Research 14(1): 65-76.

Potter-Witter, K. 2005. A cross-sectional analysis of Michigan nonindustrial private forest landowners. Northern Journal of Applied Forestry 22(2): 132-138.

Raedeke, A. H., Nilon, C. H., and Rikoon, J. S. 2001. Factors affecting landowner participation in ecosystem management: A case study in south-central Missouri. Wildlife Society Bulletin 29(1): 195-206.

Sargent, M.S and Carter, K.S., ed. 1999. Managing Michigan Wildlife: A Landowners Guide. Michigan United Conservation Clubs, East Lansing, MI. 297 pp. Accessed May 12, 2010 from: http://www.dnr.state.mi.us/publications/pdfs/huntingwildlifehabitat/landowners_gui $\mathrm{de} /$.

Sedjo, R.A., and Botkin, D., 1997. Using forest plantations to spare natural forests. Environment 39(10): 14-20. 
Serra, T., Zilberman, D., Gil, J., and Goodwin, B. 2008. Nonlinearities in the US cornethanol-oil price system. American Agricultural Economics Association. Orlando July $27^{\text {th }}$ Address.

Solomon, B. D., Barnes, J. R., and Halvorsen, K. E. 2007. Grain and cellulosic ethanol: History, economics, and energy policy. Biomass and Bioenergy 31: 416-425.

State of Michigan 2008. Granholm Says Mascoma Agreement Puts Michigan at Forefront of Next Generation Fuels. Retrieved May, $12^{\text {th }} 2010$, from http://www.michigan.gov/gov/0,1607,7-168-23442_21974-195123--,00.html.

Stone, T. 2009. What the Tree Farm Program is Really All About. Retrieved May 12, 2010, from http://www.michigantreefarm.org/05-History.htm

Tarrant, M. A., Bright, A. D., and Cordell, H. K. 1997. Attitudes toward wildlife species protection: Assessing moderating and mediating effects in the value-attitude relationship. Human Dimensions of Wildlife 2(2): 1-20.

Tyner, W. E., and Taheripour, F. 2007. Renewable energy policy alternatives for the future. American Journal of Agricultural Economics, 89(5), 1303-1310.

Tyner, W. 2008. The US ethanol and biofuels boom: its origins, current status, and future prospects. BioScience 58(7): 646-658.

U.S. Department of Agriculture. 2010. Environmental Quality Incentives Program. Retrieved May 12, 2010, from http://www.nrcs.usda.gov/programs/eqip/index.html\#prog

U.S. Department of Agriculture. 2009. Michigan forest carbon program: Carbon Sequestration on Michigan Working Forest Lands. Retrieved May 12, 2010, from http://www.wa.nrcs.usda.gov/programs/whip/WHIP09/index.html

U.S. Department of Agriculture. (2009). Conservation Reserve Program. Retrieved May 12, 2010, from http://www.nrcs.usda.gov/programs/crp/ 
U.S. Department of Agriculture. (2010). Wetlands Reserve Program. Retrieved May 12, 2010, from http://www.nrcs.usda.gov/programs/wrp/

U.S. Department of Energy (2009) Biomass Program. Ethanol Myths and Facts. Available at: http://www1.eere.energy.gov/biomass/ethanol_myths_facts.html Accessed August 23, 2010.

U.S. Energy Infomation Administration. 2010. Retail gasoline historical prices. Retrieved August 23, 2010, from http://www.eia.doe.gov/oil_gas/petroleum/data_publications/wrgp/mogas_history.ht $\mathrm{ml}$

U.S. Energy Infomation Administration. 2010. U.S. Motor Gasoline Consumption. Retrieved August 23, 2010, from: http://tonto.eia.doe.gov/dnav/pet/pet_cons_psup_dc_nus_mbblpd_a.htm

U.S. Fish and Wildlife Service. 2010. Endangered Species Program/Safe Harbor Agreements. Retrieved May 12, 2010, from http://www.fws.gov/endangered/landowners/safe-harbor-agreements.html U.S. Forest Service. 2008. Forest Legacy Program. Retrieved May 12, 2010, from http://www.fs.fed.us/spf/coop/programs/loa/aboutflp.shtml

U.S. Forest Service. 2010. Forest Stewardship Program. Retrieved May 12, 2010, from http://www.fs.fed.us/spf/coop/programs/loa/fsp.shtml

Wyman, C. E. 1999. Biomass ethanol: Technical progress, opportunities, and commercial challenges. Annual Review of Energy and the Environment 24: 189226.

Wyman, C. E. 2007. What is (and is not) vital to advancing cellulosic ethanol. Trends in Biotechnology 25(4): 153-157. 
Zhang, Y., D. Zhang, and J. Schelhas. 2005. Small-Scale Non-Industrial Private Forest Ownership in the United States: Rationale and Implications for Forest Management. Silva Fennica 39(3): 443-454. 


\section{Appendix A: Sampling Rules}

The sample size for each county is based equally upon each county's privatelyowned timberland area and the estimated number of rural property owners. "Rural" property owners are defined as those whose names are listed as parcel owners in the index of each county plat book (therefore excluding owners of small city lots).

The mathematical formula is simple. Each county's private timberland area and estimated property owners are calculated as percentages of the totals for ALL counties in the study area. These percentages are then multiplied by the pre-determined total number of letters to be mailed. The mean of these two numbers is the sample size for that county.

Example: Assume total sample size of 200 for all counties

"Smith" County:

Privately-owned timberland $=547 \mathrm{~km}^{2}$ (equals $10 \%$ of total for all counties)

Private property owners $=5825$ (equals $16 \%$ of total for all counties)

Sample size $=[(200 * 10 \%)+(200 * 16 \%)]=26$ letters to be sent to "Smith" County

\section{2}

Property owner selection is based on the now-known sample size for each county. Using the Smith county example, we know we need 26 names of property owners, and we know the estimated number of private property owners is 5825 . Divide 5825 by 26 to see that we would select every $224^{\text {th }}$ name from the owner index.

If we reach the end of the owner index and still need more names (indicating that our initial estimate of owners was off), return to the beginning of the index and select 
remaining names at the mid-points of the original increments. In the above example, we would return to the beginning of the index and select \#112, then \#336, and so forth until we reach 26 names.

If we select the name of an owner (say, \#224) who does not own at least 20 acres, go on to the next owner in the index (\#225) and see if this person owns at least 20 acres. If not, continue down the list until reaching an owner who owns at least 20 acres. This is the owner selected. In this example, the next name selected would still be \#448, regardless of how many owners we had to go past \#224 to find a suitable one.

\section{Additional rules \& notes:}

- Do not count public lands or those owned by businesses, religious organizations, hunting/recreation groups, common subdivision areas, parks, etc. Only count plots owned by individuals, married couples, families, living trusts, or any combination thereof.

- Count persons owning multiple parcels only once.

- Count husbands and wives together only once. Some county indexes list spouses separately, but most lists them together. Pay attention to this in the indexes.

- For logistical and practical reasons, parcels located on islands (for example Drummond Island) were excluded from the list of potential landowners.

- The Schoolcraft County and Delta County equalization departments were visited in person to collect the mailing addresses of landowners selected from the plat book listing. Addresses for all other counties were obtained by phone, email, fax, or regular mail. 
- Sampling increments for each county were written at the top of the first page of each county's owner index for future reference (example “every $250^{\text {th" }}$ ).

\section{The Chippewa County plat book did not feature an owner index. Consequently, a different sampling rule was necessary:}

1: Begin selection on the first page of the plat book $\left(1^{\text {st }}\right.$ map on page 5$)$ in the first quadrant (36 quadrants per page). Thus the first selection was from page 5, section 1.

-In the first quadrant select a landowner who possesses at least 20 acres and whose full last name is able to be recorded (to ensure we can get further information on the landowner from the county office). If there is no landowner in the first quadrant go on to the second then the third, etc. until a landowner is found.

-When selecting from a quadrant start in the top left corner and move clockwise until a landowner is located. Then on the next section start in the top right and move clockwise. In the next section start in the bottom right and move clockwise and finally start in the bottom left and move clockwise. Then begin the process over from the top right. 
2: For the second selection, go to page 6 , section 2 , go to quadrant two and continue in this fashion (page 6 section 2...page 7 section $3 \ldots$ page 8 section 4 ) until 55 names have been sampled.

3: Once the plat book has been completely cycled through, return to the first page and sample in reverse. (Select landowner from page 5 section 36...then Page 6 section $35 \ldots$ page 7 section 34$)$

4: Due to the fact that there is no listing of names in the Chippewa County plat book, the lower limit of parcel size was increased to 40 acres because any parcel with less than 40 acres only had the landowner's initials. However, at 40 acres we were able to get a last name and first initial which we could then in combination with the parcel location and size determine the identity of the landowner. 


\section{Appendix B: Interview cover letter designed to solicit landowner participation}

Dear,

I am a student at Michigan Technological University doing a study of Eastern Upper Peninsula forest landowners. If you are interested and available, I would like to interview you. It would help me greatly with my project if I could ask you a series of questions about your goals for your land, including the woods and wildlife.

This is a unique opportunity for you to help me learn what makes the Eastern Upper Peninsula special. You would also be contributing to my research on Michigan forest landowners' views and concerns regarding their land.

I know that you are a busy person and that your time is valuable. This interview should take 30 to 60 minutes to complete, and can be conducted over the phone at a time of your convenience. Your answers to my questions will be confidential and will never be associated with your name. I will not share your name with others.

If you are willing to be interviewed, the easiest way to let us know is to return the enclosed form or to contact me at Michigan Technological University at my cell phone number 248-245-5751 or kjmakine@mtu.edu. If you have any questions or would like to decline to be interviewed, please feel free to contact me via the enclosed form, or above phone number or email address. If I don't hear from you, I will be contacting you some time in the next month to see if you would like to be interviewed. Thank you for considering my request. 
Sincerely,

Karl Makinen,

Michigan Technological University,

Houghton, Michigan 


\section{Appendix C: Response letter}

Please respond at your earliest convenience using the self-addressed envelope provided.

Please indicate if you are willing to participate in the study.

I am willing to be interviewed for the study:

I respectfully decline to be interviewed:

Name:

Address:

Phone Number:

E-mail:

What is the best way to contact you?

Questions or Comments:

Thank you for taking the time to reply to our request, your time is appreciated. 


\section{Appendix D: Interview Question Protocol}

\section{Confidentiality Statement:}

Thank you for allowing us to interview you. This should take 30-60 minutes. We are interviewing forest landowners to learn about their interests and concerns regarding their land. This is part of a Michigan Technological University research project. Although none of our questions are very personal or sensitive, your answers are confidential. They will only be used for our research and your name will not be associated with anything you say. It helps us to have a full record of what you say if we can tape record our interview. Are you comfortable with this?

\section{Interview Questions}

\section{A. General}

1. Can you tell us about your land? (Probes: How many acres do you own? How much is forested? What kinds of trees? How much, if any, is farm field? Old fields converting to forest?)

2. What are your main reasons for owning your land? What are some of your favorite things about it? How long have you owned it?

3. What do you like to do on your land?

4. Some people view themselves as actively working with or managing their land to make it the way they want; others are more "hands-off". Do you see yourself as of these? 
5. What are your goals for your land? What would you like it to be like in 10-20 years?

\section{B. Land Management [transition]}

6. Do you have any problems happening on your land or any concerns for the future?

(Probe: For example, some people we meet mention concerns about soil quality or erosion, insects or other nuisance species, tree diseases, fire, human activities, etc.)

[If yes] Do you know of anything that could be done about it? Are you doing anything to address these concerns?

7. Have you ever met with a forester or logger to discuss management of your land? [If yes] Why and when? Do you have a management plan for your land? [If yes again] Can you tell us about the management plan and what it contains?

8. As you think about other people who own land, maybe neighbors or friends, are there people who come to mind that you think take really good care of their land? [If yes] What is it that you like about what they do?

9. Have you heard of the term "invasive species"?

[If yes] What do you know about them? Do you know if you have any invasive species on your land?

[If yes again] Are you concerned about these?

\section{Forest Management [transition]}


10. Have you ever cut trees on your land?

[If yes] When did that happen? For what purpose?

11. Do you plan to cut trees in the future?

[If yes] Can you describe your plans? For what purpose, personal firewood or selling timber/pulp? How many acres? Would it be clearcut or selectively thinned?

12. [If any sort of harvest is planned] You mentioned...(things they value from question\#2)...Would you worry that cutting activities could impact those things? Are there things that could be done to minimize any possible impacts? What?

13. Have you heard of government programs where forest landowners get a tax break or shared costs to manage their forests?

[If yes] What have you heard?

\section{[If no, explain that they exist]}

14. Would you consider enrolling your land in any of these programs? Why or why not?

\section{Wildlife management [transition]}

15. What kinds of wildlife do people see around here?

16 Are you interested in managing for wildlife on your land?

[If yes] Do you feel you have a sense of things you could do on your land to attract wildlife or give them good habitat? Do you do this already? What do you do? 
17. Are there any wetlands, streams, or ponds on your land?

[If yes] Please tell us about them.

18. Are you familiar with any government programs that are available to help landowners manage for wildlife by improving habitats or restoring wetlands? [If yes] Which programs? Would you consider enrolling in one of these types of programs? Why or why not? [If no, explain that they exist]

\section{E. Bioenergy [transition]}

19. Have you heard the phrase "energy independence"?

[If yes] What have you heard? What does it mean to you? Do you think it's an important goal? Why or why not?

20. Have you heard of the term woody "bioenergy"?

[If no, explain] It basically refers to energy produced from plant materials, such as trees, grasses, or corn.

[If yes] How about woody biofuel or cellulosic ethanol? What have you heard?

21. There are several newer companies in the U.P. that use forest materials to produce energy, including a power plant in L'Anse, a couple of wood pellet manufacturers, and a facility in Kinross that will be producing cellulosic ethanol for cars. They might be interested in buying forest materials from landowners such as you to produce energy. Have you heard about these types of companies in our area?

[If yes] What have you heard? 
22. Do you think you would be interested in cutting trees from your land to sell to these types of companies? Why or why not?

23. Some people are planting fast growing trees, such as poplar, or grasses like switchgrass, in order to produce fast growing material that could be used for bioenergy. Is this something that you think you would ever do? Why or why not?

24. What do you think of when you hear the terms "climate change" or "global warming"? [If not clear] Do you think it's not happening, is part of natural cycles, or is caused by humans? Do you think it will be a problem?

[If yes] Would you be interested in managing your land to help prevent it?

[If yes] Have you heard of carbon offset programs?

[If yes] Would you be interested in selling carbon offsets from your land?

\section{G. Closing questions [transition]}

25. What do you do (or did) you or your spouse do for a living?

26. How far did you go in school?

27. Would you like any additional information about any programs related to land management?

28. Do you have any questions for us?

29. [Any questions from note-taker?] 